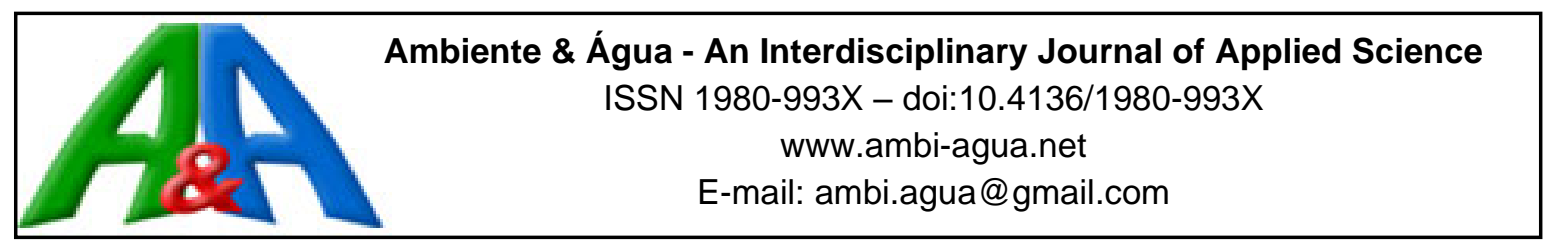

\title{
An assessment of atmospheric deposition of metals and the physico - chemical parameters of a rainwater harvesting system in Rio de Janeiro Brazil, by means of statistical multivariate analysis
}

\author{
ARTICLES doi:10.4136/ambi-agua.2522
}

Received: 27 Jan. 2020; Accepted: 08 Jun. 2020

\author{
Gabrielle Nunes da Silva ${ }^{1^{*} \text {; }}$; Letícia Delduque Alves ${ }^{1}$ (D); \\ Isabella Escobar dos Santos ${ }^{2}$; Daniele Maia Bila1 ${ }^{1}$; \\ Alfredo Akira Ohnuma Júnior ${ }^{1}{ }^{D}$; Sérgio Machado Corrêa ${ }^{2}$ ito \\ ${ }^{1}$ Departamento de Engenharia Sanitária e do Meio Ambiente. Faculdade de Engenharia. Universidade do Estado \\ do Rio de Janeiro (UERJ), Rua São Francisco Xavier, n 524, CEP: 20550-900, Rio de Janeiro, RJ, Brazil. \\ E-mail: leticiadelduque@gmail.com,danielebilauerj@gmail.com, akira@uerj.br \\ 2Departamento de Química e Ambiental. Faculdade de Tecnologia. Universidade do Estado do Rio de Janeiro \\ (UERJ), Rodovia Presidente Dutra, KM 298, CEP: 27537-000, Resende, RJ, Brazil. \\ E-mail: isabellaescobar1997@gmail.com, sergiomc@uerj.br \\ *Corresponding author. E-mail: nunes.silva.gabrielle@gmail.com
}

\begin{abstract}
This study evaluates the rainwater harvesting system to determine the chemical quality of the water and allocate it for use. Samples were collected in the city of Rio de Janeiro at the points of Direct Precipitation (DP), First Flush (FF) and Reservoir (RR). The methodology involved carrying out an analysis of $\mathrm{Ca}, \mathrm{Cd}, \mathrm{Cu}, \mathrm{Na}, \mathrm{Ni}, \mathrm{Fe}, \mathrm{K}, \mathrm{Mg}, \mathrm{Pb}, \mathrm{Zn}$, conductivity, turbidity, $\mathrm{pH}$ and chloride. The $\mathrm{R}$ language was used for the principal component analysis, Pearson coefficient correlation, hierarchical cluster analysis, Tukey test and boxplot. The results show that when there is no interference from the catchment surface (DP), the rainwater has a low concentration of metals, although the first millimeters of rain have a concentration above what is permissible in the guidelines issued by the Ministry of Health (Ordinance $\mathrm{n}^{\circ}$ 05/2017). The disposal system (FF) reduced the concentration of pollutants in the RR, but not enough to comply with legislation. It was noted that $\mathrm{Ca}, \mathrm{K}$ and $\mathrm{Na}$ are the main metals found in rainwater. During the dry period, there were significant correlations between the physicochemical and meteorological parameters. The high concentration of metals in the wet period suggests that rain assists the cleaning of the atmosphere and that most metals are present in the form of aerosols or fine particles suspended in the air. The findings reveal significant indications of acid rain and pre-treatment is recommended to ensure rainwater can be used safely for more mundane purposes.
\end{abstract}

Keywords: metals, multivariate statistical analysis, urban environment, water quality.

This is an Open Access article distributed under the terms of the Creative Commons Attribution License, which permits unrestricted use, distribution, and reproduction in any medium, provided the original work is properly cited. 


\section{Avaliação da deposição atmosférica de metais e dos parâmetros físico- químicos de um sistema de captação de águas pluviais no Rio de Janeiro Brasil, por meio de uma análise estatística multivariada}

\section{RESUMO}

Este estudo avalia o sistema de captação de água da chuva para verificar a qualidade química da água e alocá-la para uso. As amostras foram coletadas na cidade do Rio de Janeiro, Brasil, na Precipitação Direta (DP), First Flush (FF) e Reservatório (RR). A metodologia consiste em análises de $\mathrm{Ca}, \mathrm{Cd}, \mathrm{Cu}, \mathrm{Na}, \mathrm{Ni}, \mathrm{Fe}, \mathrm{K}, \mathrm{Mg}, \mathrm{Pb}, \mathrm{Zn}$, condutividade, turbidez, pH e cloreto. A linguagem $\mathrm{R}$ foi utilizada através da análise de componentes principais, correlação linear de Pearson, análise hierárquica de agrupamentos, teste de Tukey e boxplot. Os resultados indicam que a água da chuva sem interferência da superfície de captação (PD) apresenta baixa concentração de metais, porém os primeiros milímetros de chuva apresentam uma concentração acima da permitida pela Portaria $\mathrm{n}^{\circ}$ 05/2017 do Ministério da Saúde. O sistema de descarte (FF) reduziu a concentração dos poluentes no RR, mas não o suficiente para atender a legislação. Observou-se que $\mathrm{Ca}$, $\mathrm{K}$ e Na são os principais metais encontrados na água da chuva. O período seco apresentou correlações significativas entre os parâmetros físico-químicos e meteorológicos. A alta concentração de metais no período úmido indica que a chuva promove a limpeza da atmosfera e que a maioria dos metais está presente na forma de aerossóis e em partículas finas suspensas no ar. Os resultados indicam características de chuva ácida e sugerese o pré-tratamento da água da chuva para uso com segurança em fins menos nobres.

Palavras-chave: ambiente urbano, análise estatística multivariada, metais, qualidade da água.

\section{INTRODUCTION}

Water is essential for maintaining the life cycle on earth. The demand for water is increasing more rapidly than population growth throughout the world, and this is causing an imbalance between the consumption and availability of water resources. Management failure and a lack of information on the current situation of natural resources, combined with unsustainable development, can have an adverse effect on the availability and quality of water. There are a number of factors that harm the quality of water, such as urbanization, pollution, deforestation and unsuitable agricultural practices (UNESCO, 2015). About 3.6 billion people live in areas where there is likely to be a scarcity of water for at least one month a year, and it is predicted that this number could increase to $4.8-5.7$ billion by 2050 . The population currently affected by land degradation/desertification and drought is estimated to be about 1.8 billion people, which makes this the most significant category of natural disaster (WWAP, 2018).

Rainwater harvesting is a freely available source that can meet the requirements for water in different regions of the world, especially in places where there is a shortage or lack of access to water of a good quality (Alim et al., 2020). In addition, the rainwater system reduces the municipal consumption of water and mitigates the harmful consequences of urban stormwater runoff in extreme events (Ghaffarianhoseini et al., 2015). Despite the large amount of water available in Brazil, many regions suffer from a lack of a supply and distribution of water and long periods of drought, especially in the country's semi-arid regions. In rural areas, rainwater is generally used to meet basic demands, including human consumption, while in urban areas rainwater is used as a supplementary source to serve secondary demands (Gomes et al., 2014).

In developing countries, rapid industrialization and urbanization have increased the problem of metallic air pollutants that damage the environment and are a hazard to human health (Lu and $\mathrm{Yu}, 2018$ ). Air contaminants can chemically affect rainfall, especially during the dry season (Mimura et al., 2016). Several factors, such as mesoscale circulation, topography 
and local sources influence the chemical composition of precipitation (Vieira-Filho et al., 2013). High levels of $\mathrm{Zn}$ and $\mathrm{Pb}$ have been found in rainwater, which may be caused by metal leaching from roofing, and storage tanks or through atmospheric pollution (WHO, 2008). In a clean atmosphere, the $\mathrm{pH}$ of rainwater is around 5.6 (Charlson and Rodhe, 1982) whereas a lower $\mathrm{pH}$ is characteristic of acid rain, which is caused by the presence of $\mathrm{SO}_{2}$ and $\mathrm{NO}_{\mathrm{x}}$ oxidation, and leads to the bioavailability and dissolution of trace- and major metals in rainwater (Anil et al., 2017; Oliveira et al., 2012). The main sources of metals in the atmosphere are petroleum refineries, waste incinerators, coal burning power plants, metal treatment services, fuel combustion and road traffic (Connan et al., 2013). The trace metals present in urban areas can be found in the roofing, electronic materials, paintwork and the components of automobiles (Le Pape et al., 2012).

The presence of $\mathrm{NO}_{\mathrm{x}}$ and $\mathrm{SO}_{2}$ in rainwater can be attributed to fossil fuel combustion, mainly vehicular and industrial emissions. Resuspended particles and other contaminants can be carried through the atmosphere and are responsible for various chemical and physical processes (Martins et al., 2014). Particulate matter (PM) and gases present in the atmosphere during rainout and washout are incorporated into the water droplets, which act as a water distiller (Conceição et al., 2011), and reach the surface of the earth and water resources. After this, the pollutants are removed from the atmosphere by wet and dry deposition (Szép et al., 2019). Atmospheric deposition is responsible for the spatial redistribution and continuous cycling of chemical elements through the removal of particles and gases by snow, rain or mist in the wet phase or, in the absence of rainwater, in the dry phase (Ohnuma et al., 2014).

The relative humidity influences the solubilization of water-soluble pollutants in the form of aerosols by means of wet deposition, thus triggering the most effective aqueous phase reaction (Gioda et al., 2017). Thus, urban and, in particular, industrial areas pose a risk to aquatic species owing to the bioaccumulation of elements, such as toxic metals associated with PM that are present in atmospheric emissions (Mateus et al., 2018). The effect of metals on the environment and the atmosphere has become a serious hazard, since the accumulation of toxic metals in human body tissue through inhalation and being passed through the food chain can cause damage to internal organs and the nervous system (Kamani et al., 2014).

The results of revised work on rainwater harvesting systems show an average potential savings of 53\% can be made in drinking water (Ghisi et al., 2018). These systems have aroused considerable interest and play an important role in increasing the availability of water, reducing adverse impacts on the environment, improving human health (Diehl de Souza and Ghisi, 2020) and providing economic benefits (Pavolová et al., 2019). In Brazil, there are no monitoring networks for acid precipitation and only a few studies on the subject have been carried out, mainly concentrated in the Southeast and Southern regions (Martins et al., 2019), which are areas at risk owing to intense urbanization and industrial activity.

The physical and chemical characterization of rainwater helps to assess the influence of different sources of pollution and the regional and local dispersion of gases and particles, in addition to their possible impact on the ecosystem (Laouali et al., 2012). Furthermore, it is essential to understand the relationship between air pollution and water and determine the nature of the compounds present in the rain and their concentrations, since the available data are limited (Gasperi et al., 2014).

This study was carried out in the urban area of Rio de Janeiro, Brazil, between November 2017 and October 2018 with the following objectives: (i) to analyze the physico-chemical composition and presence of metals in rainwater; (ii) to apply multivariate statistics using the $\mathrm{R}$ language to assess the pattern of behavior of the physico-chemical and meteorological parameters during the dry and rainy season; and (iii) to compare the findings about these parameters with the drinking-water quality standards set by the Ministry of Health (Ordinance $n^{\circ} 05 / 2017$ ) when deciding on uses for rainwater. 


\section{MATERIALS AND METHODS}

\subsection{Study area}

The city of Rio de Janeiro has approximately 6.7 million people spread over 1,200 $\mathrm{km}^{2}$ (IBGE, 2019); about $36 \%$ of this area is covered by vegetation, mainly the Tijuca National Park which comprises $40 \mathrm{~km}^{2}$ (Braga et al., 2018). The Tijuca Forest is an area of mountainous tropical forest that forms a natural barrier to air circulation (Silva et al., 2016b), and is regarded as the largest urban secondary forest in the world (Silva et al., 2016a). Its topography, geographic location, the use and the occupation of the soil and proximity of the oceanic region result in a complex rainfall pattern (Brito et al., 2017; Siciliano et al., 2018) (Figure 1).
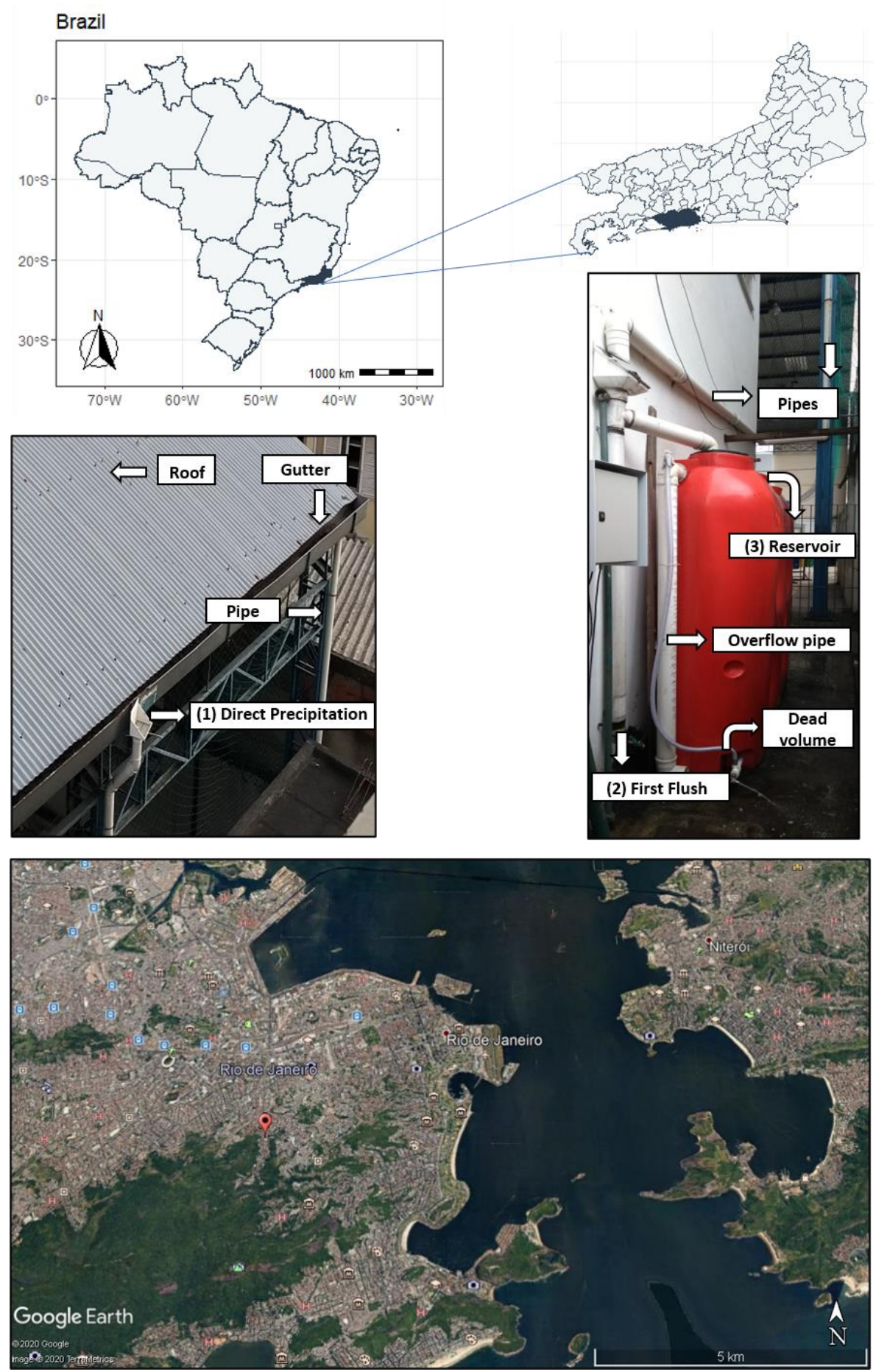

Figure 1. The study area and collection points. 
The Geo-Rio Foundation monitors rainfall in the city of Rio de Janeiro - RJ through 33 strategically-located rainfall stations. It is an early-warning system for landslides and heavy rainfall in the city of Rio de Janeiro. According to the historical series from 1997 to 2016, the average annual total for the area is $1,212 \mathrm{~mm}$. The highest rainfall occurs in the month of January, when there is an average rainfall of $176.6 \mathrm{~mm}$, and August is the driest period with $39.8 \mathrm{~mm}$ (GEO-RIO, 2018).

The rainwater harvesting system is located on the roof of the multi-sport facility building at the college of the State University of Rio de Janeiro (CAp-UERJ), together with a catchment area of $80 \mathrm{~m}^{2}\left(22^{\circ} 55^{\prime} 39.4^{\prime \prime} \mathrm{S} 43^{\circ} 12^{\prime} 30.4^{\prime \prime} \mathrm{W}\right)$, in the district of Rio Comprido, in the northcentral region of the city of Rio de Janeiro. The location is in one of the main north-south transition zones of the city, where there is heavy road traffic. During a precipitation event, rainwater passes through the roof, flows along conduits to the coarse solid filtration point using a $1.0 \mathrm{~mm}$ mesh. Then, the water is sent to the first flush (FF) disposal system, which has an accumulated storage capacity of $0.20 \mathrm{~mm}$ of rain. After reaching this, the rainwater goes directly to the 2,460-liter fatboy slim reservoir with polyethylene coating. If the volume of the reservoir reaches full capacity, the overflow system is activated.

\subsection{Sampling and chemical analysis}

The analysis of the physico-chemical and rainfall data of the collections carried out from November, 2017 to April, 2018 allowed this to be characterized as a wet period $(\mathrm{N}=7)$, and the samples obtained between May and October, 2018 were defined as a dry period $(\mathrm{N}=6)$. The sampling campaign was carried out from three specific points: (1) Direct Precipitation (DP): the collection point without interference from the intake system, that was only influenced by local atmospheric conditions, and had the capacity to store up to $700 \mathrm{~mm}$ of accumulated precipitation; (2) First Flush (FF): the initial capture of rain with a mixture of wet and dry deposition. This has the capacity to store $0.2 \mathrm{~mm}$ of precipitation and (3) Reservoir (RR): where the quality of the stored water determines the operations of the initial disposal system (FF) and the possible use of water. The RR point is located about 0.40 meters from the bottom level of the reservoir and has a capacity to store up to $23.66 \mathrm{~mm}$ of precipitation. This study disregards analyses of samples of the dead volume stored in the reservoir, as it is concerned with its potential use and the operating conditions of the system.

The pluviometric data were obtained from the Rio Early Warning System (Alerta Rio, 2018) operated by the City Hall, and corresponds to the number 4 pluviometer located in the district of Tijuca. The Tijuca station is about $1 \mathrm{Km}$ from the location of this study. Thirteen campaigns were carried out to collect rainwater and the samples were collected monthly in $1 \mathrm{~L}$ polyethylene bottles. The stages for the preparation and sample collection were based on the National Sample Collection and Preservation Guidance Manual of the National Water Agency (ANA, 2011). The chemical analysis of the metals involves a special procedure of washing the vials and lids by immersion in a $10 \%$ nitric acid solution for $48 \mathrm{~h}$, and then rinsing them with MilliQ water 5 times; after this, they are dried on absorbent paper and stored in a dry and clean place to avoid contamination. After each collection, $1 \mathrm{~L}$ of sample was vacuum filtered through a $47 \mathrm{~mm}$ glass fiber filter (Merck Millipore) with $0.7 \mu \mathrm{m}$ porosity and acidified with $\mathrm{HNO}_{3} 1: 1$ until $\mathrm{pH}<2$.

Greater precision in the quantification of the metals present was achieved by concentrating the samples with the aid of a heating plate at a temperature of 80 to $90^{\circ} \mathrm{C}$ to reduce the volume from $250 \mathrm{~mL}$ to $10 \mathrm{~mL}$. Straight after this, $40 \mathrm{~mL}$ of $\mathrm{HNO}_{3}\left(3 \mathrm{~mol} \mathrm{~L}^{-1}\right)$ was added, after which the samples were transferred to $50 \mathrm{~mL}$ Falcon tubes which were pre-washed with $\mathrm{HNO}_{3}$ and stored in the refrigerator at a temperature of $4^{\circ} \mathrm{C}$ until the time of analysis. The cleaning of the flask for the analysis of $\mathrm{pH}$, turbidity, chloride and conductivity entails washing the bottles and lids with distilled water. The samples were kept on ice until they arrived at the laboratory. It was not possible to perform blank in the field due to the difficulty of accessing the area of the 
rainwater catchment system. The blank was carried out in the laboratory with the collected rainwater and $\mathrm{HNO}_{3}$ used to wash the flasks and in the physico-chemical analyses.

The $\mathrm{pH}$ buffer solution was used in the $\mathrm{pH}$ meter calibration for samples in the acid range of $\mathrm{pH} 4$ solution, and for the basic range of $\mathrm{pH} 10$ solution. The turbidimeter was calibrated to the standards of $0.1 \mathrm{UNT}, 8 \mathrm{UNT}, 80 \mathrm{UNT}$ and $1000 \mathrm{UNT}$. The conductivity meter was calibrated in accordance with the Digimed DM-S6A conductivity standard. The chloride was determined by potentiometry in triplicate using $1 \mathrm{~mL}$ of the $50 \mathrm{~g} \mathrm{~L}^{-1}$ potassium chromate solution and $0.013 \mathrm{~mol} \mathrm{~L}^{-1}$ silver nitrate solution for $50 \mathrm{~mL}$ of the sample.

The analytical methodology is based on the Standard Methods for the Examination of Water and Wastewater (APHA et al., 2012). The 10 elements: Calcium (Ca), Cadmium (Cd), Copper $(\mathrm{Cu})$, Iron $(\mathrm{Fe})$, Potassium (K), Manganese (Mn), Sodium $(\mathrm{Na})$, Nickel $(\mathrm{Ni})$, Lead $(\mathrm{Pb})$ and Zinc ( $\mathrm{Zn}$ ) were analyzed by means of the Flame Atomic Absorption Spectroscopy (EAA) method 3-14 with a quantification limit between 0.01 and $0.02 \mathrm{mg} \mathrm{L}^{-1}$, in the PerkinElmer AAnalyst 400 equipment, installed in Resende - RJ, at the Faculty of Technology of the State University of Rio de Janeiro.

Standards were used for the analytical curves, at concentrations of 10, 50, 100, 300, 500 and $1000 \mu \mathrm{g} \mathrm{L}^{-1}$. An additional standard of $5000 \mu \mathrm{g} \mathrm{L}^{-1}$ was used for iron. Acetylene was used as a fuel to determine the concentration of metals and compressed air as an oxidizer, with a flame temperature of $2100^{\circ} \mathrm{C}-2400^{\circ} \mathrm{C}$. However, in the case of the most refractory element such as $\mathrm{Ca}$, it was necessary to replace compressed air with nitrous oxide, which has a flame temperature of 2500 to $3100^{\circ} \mathrm{C}$. The concentration was determined at room temperature, with deionized water used between the analyses. When the sample reading was above the maximum calibration point, the sample was diluted with $\mathrm{HNO}_{3}$ solution. The analytical curve was assessed every day before the samples were read.

\subsection{Statistical analysis}

The result of a chemical experiment involves analyzing several interrelated variables, and for this study Language R version 3.4.4 (R Core Team, 2018) was applied so that the data could be handled with multivariate statistics. The R package called FactorMineR was applied for the multivariate data. This package is characterized by the use of different data structures, and quantitative or categorical variables (Lê et al., 2008). Pearson's correlation coefficient was used to determine the behavior of one variable in relation to another. The Tukey test was also conducted to compare the data subsets.

The Principal Component Analysis (PCA) led to the linear transformation of the data and enabled the values resulting from this transformation to have their key components in the first dimensions (i.e., in the main denominated axes), with the least possible loss of information (Lyra et al., 2010). Hierarchical cluster analysis was carried out with the aim of dividing a set of objects into several groups to ensure that the objects within the same group are more similar to each other (Bratchell, 1989). These are techniques that are considered to be essential in the analysis of chemical data (Luna et al., 2014; Moita Neto and Moita, 1998).

The experiment involved a large number of physico-chemical and meteorological variables and they had to be separated into two groups to understand the relationships between them: one group for metals and another group for the other physico-chemical variables. Meteorological parameters, such as the number of consecutive dry days and the sub-daily rainfall intensity were included in these two groups as a way of determining if there was a possible correlation. In addition, the data were interpreted by dry periods and wet periods and explained in terms of the seasonality of certain parameters.

With regard to descriptive statistics and boxplot, all the results were included, although, in the application of PCA and the linear correlation with a dendrogram, it was necessary to disregard variables that had results below the limit of quantification or that did not have any 
significant variation between the points collected. The data obtained from the Tijuca station were used for the selection of rain events, calculation of Consecutive Dry Days (CDD) and subdaily rainfall intensity. The sub-daily rainfall intensity was calculated for the first rain event $\geq$ $7 \mathrm{~mm}$ that occurred in the period between the collections from the reservoir for analysis of samples. The CDD represents the sum total of successive days with less than $1 \mathrm{~mm}$ of rain.

\subsection{Legislation}

Despite its increasing use for human consumption in areas where rain is the main source of supply, as well as for more mundane purposes, the use of rainwater in Brazil is not subject to legislation. As an alternative, the use of drinking water legislation is applied in several studies to determine possible uses (Alcolea et al., 2015; Despins et al., 2009; Hoseinzadeh et al., 2016; Igbinosa and Aighewi, 2017; Magyar et al., 2008; Olaoye and Olaniyan, 2012; Senevirathna et al., 2019; Yaziz et al., 1989). Although a number of projects for rain-use have been undertaken in many countries, they have been designed for conserving water, without taking note of other benefits that can be derived from the multi-purpose nature of rainwater catchment and storage systems (Campisano et al., 2017).

In Brazil, Ordinance $n^{\circ}$ 05/2017 of the Ministry of Health (Brasil, 2017) regulates the procedures for controlling and monitoring the quality of water for human consumption and its drinking water quality standards. In addition to the WHO recommendations, the ordinance standardizes the permissible limits for metals, and thus the measures stipulated by the legislation of the Ministry of Health (MS) were selected for the comparison of results.

\section{RESULTS AND DISCUSSION}

Thirteen rainwater samples were collected during the period 2017-2018. Analyses of pH, chloride, conductivity, turbidity, metals and rainfall were performed at the points of DP, FF and RR. Pearson's correlation coefficient with a dendrogram was applied to define the possible sources of certain elements and to determine the relationships between the physico-chemical parameters of the rain composition. PCA was applied to a set of variables, both to reduce their dimensionality and to investigate the relationship between the elements of rainwater and the possible sources of pollution. The Tukey graph was used to compare the averages obtained between the points of collection of certain parameters. The results are divided into dry and wet periods and the averages are shown with the standard deviation of each series. Ordinance $n^{\circ}$ 05/2017 of MS was used as a basis for comparing the results obtained.

\subsection{Physico-chemical parameters}

In general, the results of $\mathrm{pH}$ and turbidity are beyond the limits of what is permitted by Ordinance $n^{\circ}$ 05/2017; chloride meets the standard and conductivity has no limit (Table 1 and Figure 2). The wet deposition obtained by the DP maintained its acidic properties in the dry and wet periods. High turbidity was observed in the dry period. The highest concentrations of chloride were observed in the dry period, although the samples of DP in the wet period obtained the highest average of $10.45 \pm 3.41 \mathrm{mg} \mathrm{L}^{-1}$.

The presence of chloride in rainwater samples can be attributed to marine aerosols and the proximity to the sea, as was also reported in a study carried out in the Alto de Sorocaba Basin in Southeast Brazil (Conceição et al., 2011) and in Greece (D’Alessandro et al., 2013), or it might be derived, for example, from the dissolution of evaporated minerals in the form of soil dust (Wu et al., 2012). In addition to natural emissions, $\mathrm{Cl}^{-}$can be attributed to pollution, mainly from human activities such as burning biomass, vehicular traffic and the decomposition of organochlorine compounds (Conceição and Bonotto, 2004; Négrel and Roy, 1998; Pelicho et al., 2006; Sanusi et al., 1996). 
Table 1. Descriptive statistics for concentrations of physico-chemical parameters. in the wet period and in the dry period.

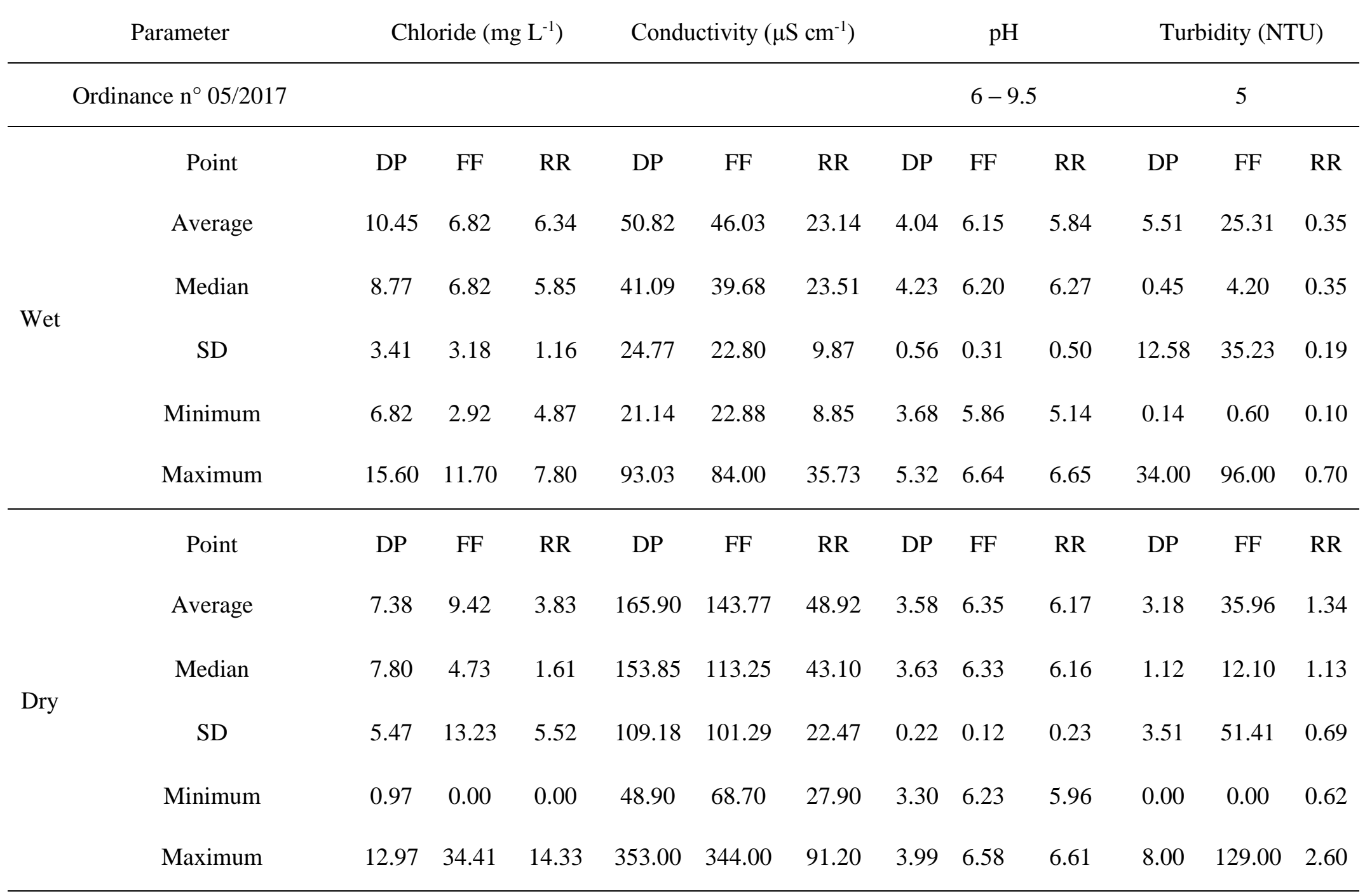

Key to initials: DP: Direct Precipitation; FF: First-Flush; RR: Reservoir; SD: Standard Deviation. 
A)

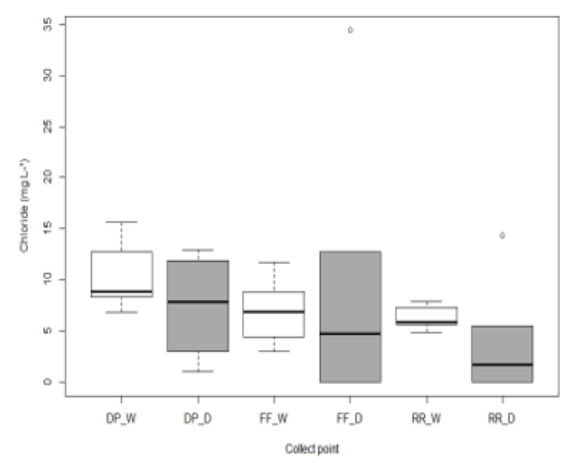

C)

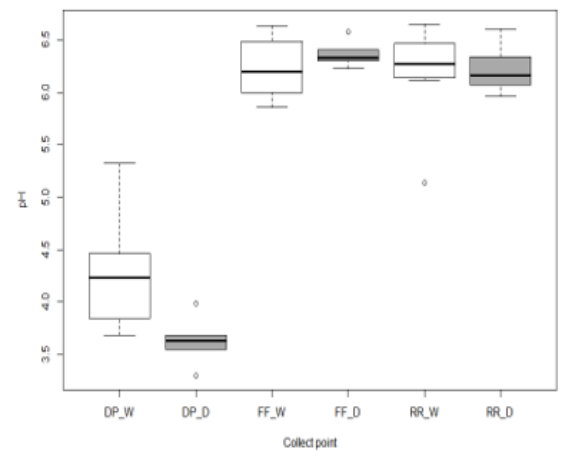

B)

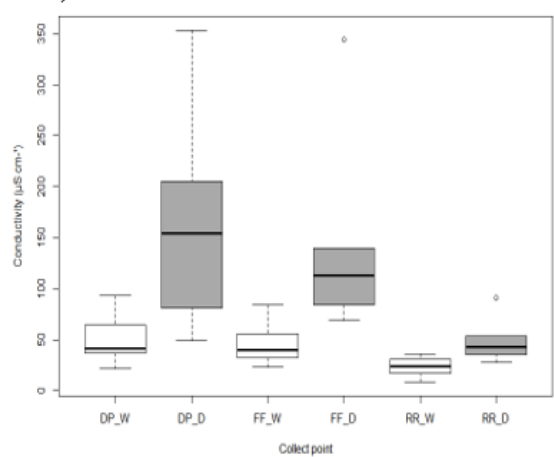

D)

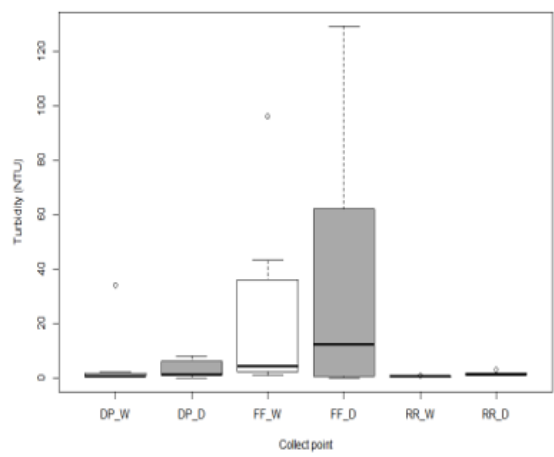

Figure 2. Boxplot for physico-chemical concentrations collected in the wet period (W) - shown in grey and dry (D) - shown in white, at the points of direct precipitation (DP), first flush (FF) and reservoir (RR).

The dry period resulted in a wider variation of concentrations, particularly in the first millimeters of rain or at the FF point, with a minimum of $0 \mathrm{mg} \mathrm{L}^{-1}$ and a maximum of 34.41 $\mathrm{mg} \mathrm{L}^{-1}$. At this stage, total deposition occurs, and consists of both wet deposition and dry deposition, which can lead to higher concentrations of chloride. The accumulation and washing of pollutants are extremely dynamic processes, where the variation can be accounted for by the continuous changes of pollutants throughout the dry period and throughout the rain event (Wijesiri et al., 2016).

The legislation does not cover conductivity limits. In the assessment of seasonality, the highest values were recorded in the dry period, with average concentrations of $165.90 \pm 109.18$ $\mu \mathrm{S} \mathrm{cm}^{-1}$ at the point of DP; $143.77 \pm 101.29 \mu \mathrm{S} \mathrm{cm}^{-1}$ at the FF point and $48.92 \pm 22.47 \mu \mathrm{S} \mathrm{cm}^{-1}$ at the RR point. Despite the high standard deviation for conductivity, especially in the dry period, according to the Tukey test which compares the means two by two, the average means are found to be statistically equal (Figure 3). In light of this, it can be assumed that the characterization of environmental data is subject to intermittent precipitation events and a wide range of meteorological elements and factors, before a greater variability can be found in the results obtained from the physico-chemical parameters. In the drier months, there is a higher concentration of particulate material, much of it in the form of dissolved solids that are deposited and accumulated on the catchment surface and can influence electrical conductivity.

Close values for conductivity were found in a study that was based on different rainwater storage systems in Greece: the first flush located in an industrial area displayed a conductivity of $143 \mu \mathrm{S} \mathrm{cm}^{-1}$, similar to this study (Gikas and Tsihrintzis, 2012). In the rainy months, the average conductivity found in the DP, FF and RR was $50.82 \pm 24.77 \mu \mathrm{S} \mathrm{cm}^{-1}, 46.03 \pm 22.80 \mu \mathrm{S}$ $\mathrm{cm}^{-1}$ and $23.14 \pm 9.87 \mu \mathrm{S} \mathrm{cm}^{-1}$, respectively, lower values than those in the period of drought. These results demonstrate that rain assists in cleaning the atmosphere through a greater dilution of the analytes, where the conductivity showed more critical values in the dry period (Mimura 
et al., 2016). All the samples analyzed resulted in conductivity below $100 \mu \mathrm{S} \mathrm{cm}^{-1}$, with a low level of mineralization (Vialle et al., 2011).

A)
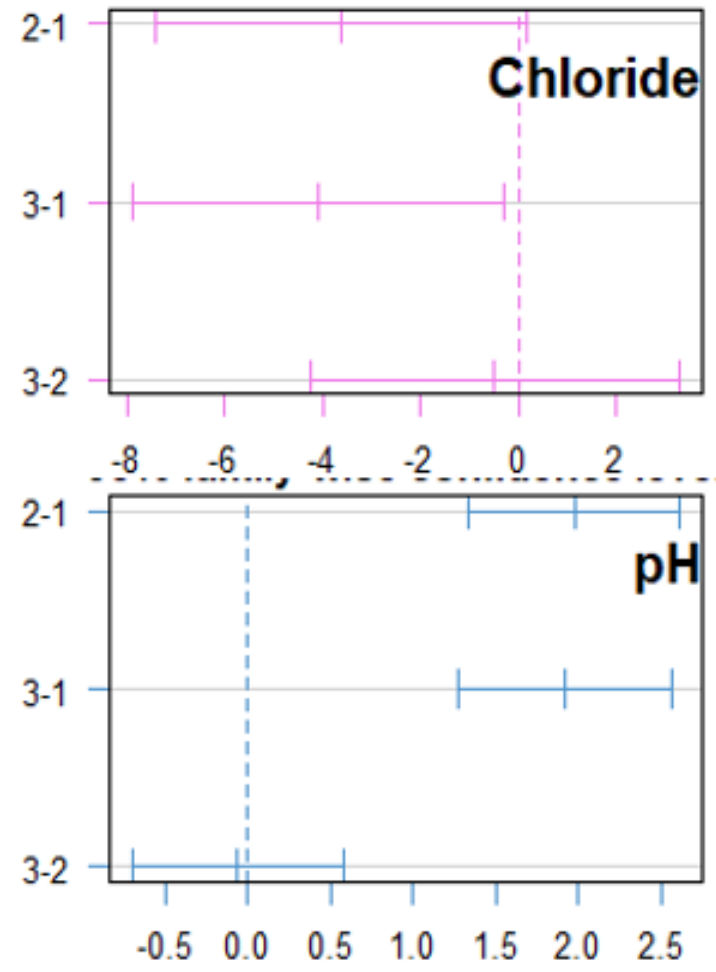

B)
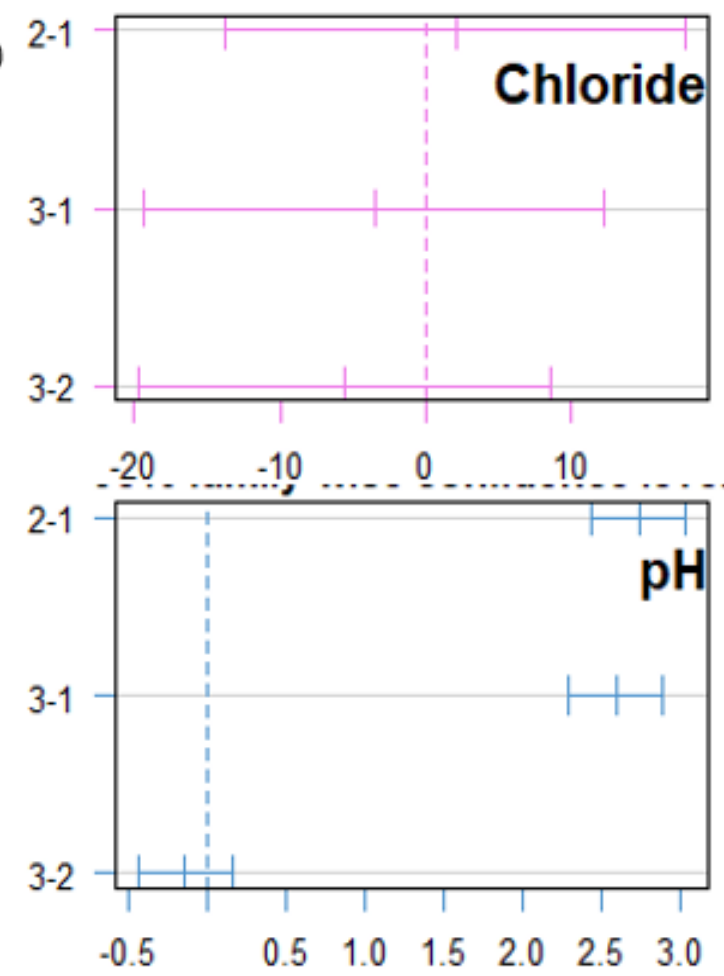
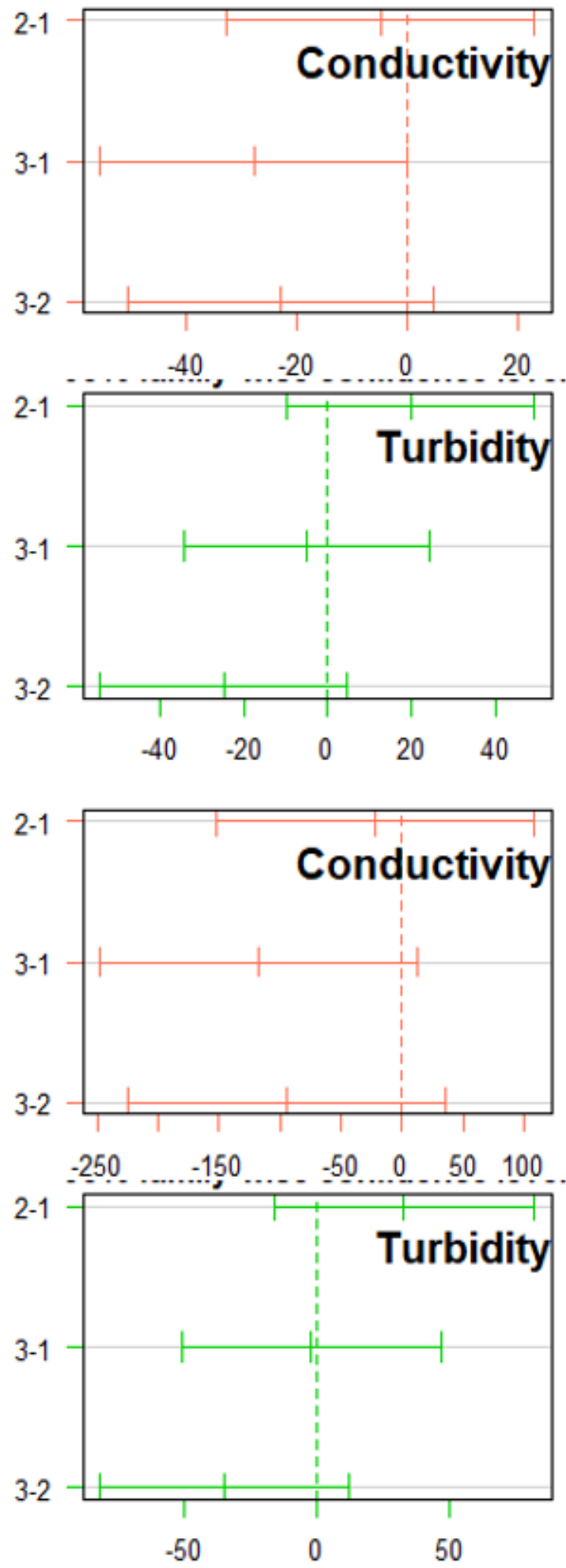

Figure 3. Tukey test for physico-chemical parameters collected in the wet period (A) and dry (B), at the points of direct precipitation (1), first flush (2) and reservoir (3).

Rainwater samples collected directly from the atmosphere in a rural area close to the forest in the city of Guarapuava, Brazil, showed a variation of $4.4-24.4 \mu \mathrm{S} \mathrm{cm}^{-1}$ (Beló et al., 2009). In Ganhaizi, and in the city of Lijiang in China, where rainwater samples were also analyzed, 
the conductivity observed in these locations during the rainy season ranged from 2.14 to 57.2 $\mu \mathrm{S} \mathrm{cm} \mathrm{cm}^{-1}$, with an average of $11.5 \mu \mathrm{S} \mathrm{cm} \mathrm{cm}^{-1}$; differences in anthropic activity may be the reason for the different results in each city (Niu et al., 2014). The conductivity found in these studies show fewer variations than in CAp-UERJ, located in an urban area and there was a high concentration of air pollution of vehicular origin.

The $\mathrm{pH}$ range of rainwater is generally between 4.0 and 6.0, with $\mathrm{NH}_{\mathrm{x}}$ being ionized and the $\mathrm{H}^{+}$ion resulting from the acid-base balance in the rain (Souza et al., 2006). Rainwater caused by dissociation of dissolved carbon dioxide $\left(\mathrm{CO}_{2}\right)$ has a natural $\mathrm{pH}$ of 5.6 (Hoinaski et al., 2014); however, this value can be reduced and the acidity increased in the presence of pollutants originating from human activities (Charlson and Rodhe, 1982). Throughout the period of analysis, the FF and RR points showed a minimum average of $5.84 \pm 0.50$ in RR (W) and a maximum of $6.35 \pm 0.12$ in FF (D). The $\mathrm{pH}$ has no direct impact on human health, although the low $\mathrm{pH}$ value in the water can lead to corrosion in rainwater storage pipes or tanks (Lee et al., 2017).

In the humid period, there is a greater variation in $\mathrm{pH}$ than in the dry period; in addition, the rain is more acidic in the less rainy period, as has also been confirmed by research on rainwater in Minas Gerais (Cerqueira et al., 2014). The highest $\mathrm{pH}$ values are found at the points where the water traveled through the roof (FF and RR), possibly as a result of the deposition of dissolved solids (Hagemann and Gastaldini, 2016). The feces of birds that are considered to be alkaline and have a high concentration of $\mathrm{NH}_{3}$ lead to an increase in $\mathrm{pH}$ at the points of total deposition. The presence of outliers was observed at the points of DP, FF and RR. These outliers are common in environmental data, especially in rainwater. The Tukey test was carried out to compare whether the data are different from each other and it was found that the PD point is statistically different from the other collection points; however, FF and RR had similar populations in the two study periods.

A study carried out in São Paulo concluded that the use of ethanol as a fuel leads to the emission of several compounds such as acetic acid and acetaldehyde directly into the atmosphere, which means that organic compounds may be responsible for about $44 \%$ of the acidity present in the wet deposition (Fornaro and Gutz, 2003). All the samples collected without roof interference (DP) were below the recommended limit for drinking use in both periods $(\mathrm{N}=13)$, which may indicate the presence of acidic substances in the atmosphere. During the first flush in the wet period, $28.57 \%$ of the samples were slightly below the permissible $\mathrm{pH}$ limit of 5.86 and 5.96. In the dry period, all the FF samples were within the permitted range. At the RR reservoir point, only one result was below 6.0 in the wet period, and the same was observed in the dry period.

Turbidity indicates the degree of attenuation that a beam of light undergoes when it passes through water (ANA, 2019). The initial precipitation is stored at the FF point; this consists of gases originating from the atmosphere and dissolved in raindrops and particulate matter found on the roof, which cause a greater incidence of turbidity at this point and considerably reduce the total suspended solids at the RR reservoir point.

Rainwater is affected by surface runoff and storage conditions (Abu-Zreig et al., 2019); the initial $2 \mathrm{~mm}$ of rain contains most of the contaminants directed to the FF disposal point (Kus et al., 2010b). In this way, the initial precipitation event removes most of the material deposited on the catchment surface and stored in the FF; this reveals the need to dispose of the first millimeters of rainwater to avoid contaminating the reservoir. The deposition of pollutants from the atmosphere over the roof surface during a certain dry period, influences the quality of rainwater. The longer the dry period between the precipitation events, the greater the probability of pollutants being deposited on the roof surface (Yaziz et al., 1989). Turbidity can be a risk to human health if the suspended particles have adsorbed toxic inorganic or organic compounds, so it is essential to avoid the first volumes of effective precipitation (Kus et al., 2010a). Results 
above the limit of 5 UNT were found in the city of Khorramabad in western Iran (Hoseinzadeh et al., 2016), at points FF and DP. FF had a total of 6 non-compliant samples, DP had few events with turbidity levels above the permitted level with $\mathrm{N}=1$ in the wet period and $\mathrm{N}=2$ in the dry period.

PCA in the wet season showed that the first and second components (DIM 1 and 2) represented $32.9 \%$ and $29.4 \%$ of the total variance, respectively. PCA of data is recommended when the sum of DIM 1 and DIM 2 is greater than 60\%. Most of the variables are well represented in the first two components in the wet season, with an emphasis on Conductivity and Chloride in the FF, which make a greater contribution to DIM 1 due to their proximity to the $\mathrm{X}$-axis and have a strong correlation with the vector size. In the first quadrant, the CDD, DP Conductivity, DP Turbidity and FF $\mathrm{pH}$ are correlated, although RR Turbidity and RR Chloride have a negative correlation because they are in opposite quadrants. The correlation between the variables in the total dataset was confirmed by the Pearson correlation coefficient, together with the Hierarchical Cluster Analysis (HCA), which were used to visualize the clusters and possible correlations. The search for clusters between the variables was an additional way of studying the structure of the results provided by the PCA with the HCA.

In the wet season, most correlations between physico-chemical parameters are weak, and the highest correlations occurred between the Turbidity in the DP and the CDD and between Conductivity and Chloride in FF, which suggests that Chloride ions may increase the rainwater Conductivity. In this study, the relationship between CDD and Turbidity is directly proportional, i.e., the longer the time interval without rain, the greater the accumulation of suspended particles in the atmosphere that increase turbidity in DP. The correlation is null between the Turbidity in the DP and the Turbidity in the RR. The Turbidity in the RR might be related to the solids deposited in the roof and the DP Turbidity is only influenced by the atmospheric conditions. In the Pearson correlation dendrogram 3 clusters are formed. RR Turbidity, DP pH, FF Chloride and FF Conductivity, form the lowest group and these parameters are not connected to the other clusters, which shows a low correlation (Figure 4).

A)

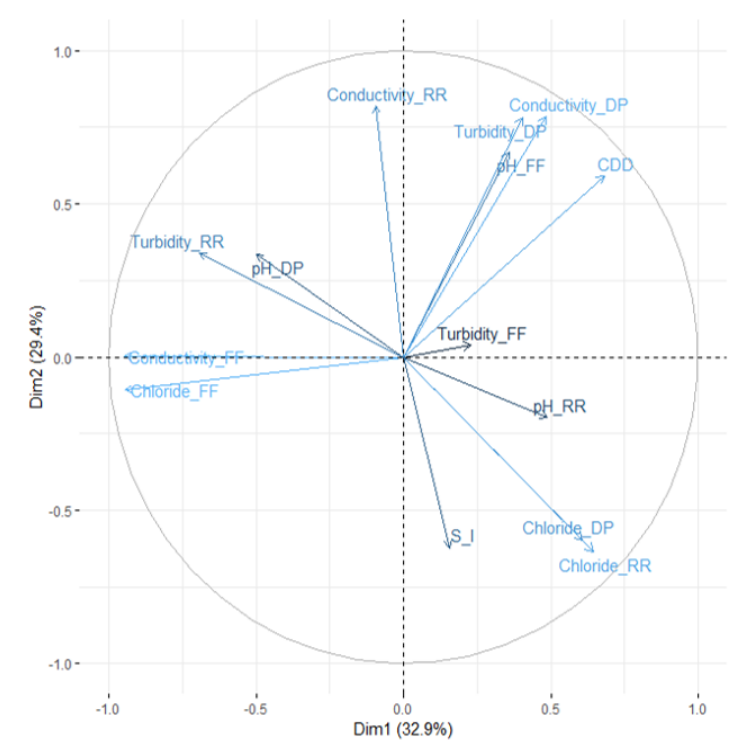

B)

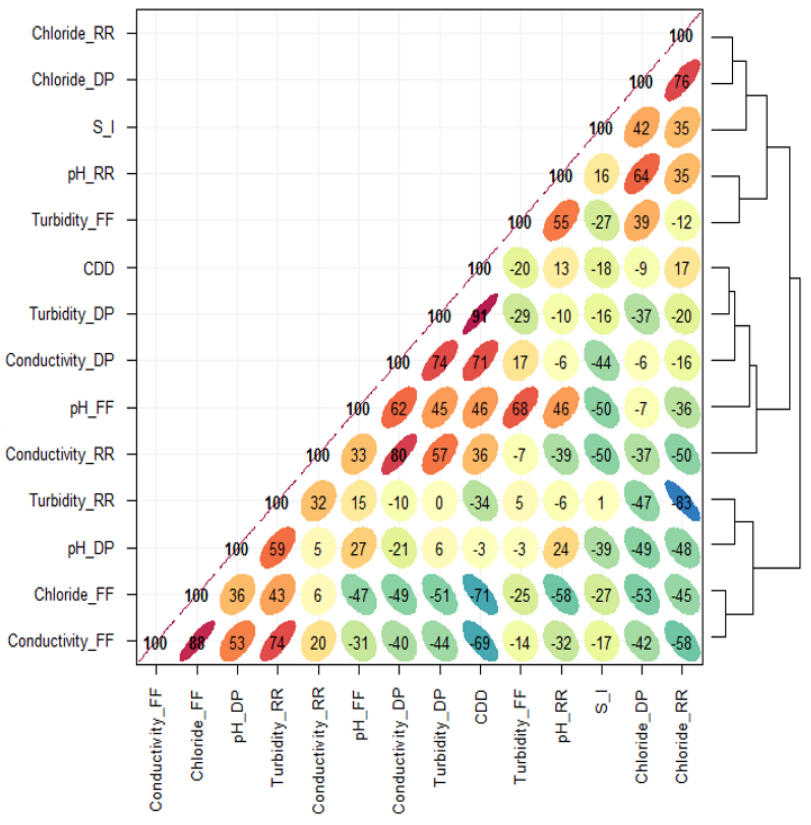

Figure 4. (A) Principal component analysis (PCA) and (B) Pearson correlation matrix, together with the hierarchical cluster analysis (HCA) of physico-chemical and meteorological parameters in the wet period - in direct precipitation (DP), first flush (FF) and reservoir (RR). CDD: Consecutive dry days; S_I: Sub - diurnal rainfall intensity. 
The PCA shows most of the variables are close to each other in the dry season; this represents a strong correlation, and suggests a greater contribution is made to the DIM 1 eigenvector (Figure 5). The PCA also includes two main groups: sub-rainfall intensity, RR Turbidity, DP $\mathrm{pH}$ and Conductivity and FF Turbidity are in the first cluster and the other parameters in the second cluster. The FF and RR Chloride are closely correlated, as well as the FF Conductivity and RR Conductivity and FF Chloride and Conductivity. Conductivity indirectly measures the presence of ions dissolved in the water, among them the Chloride ion. There are close correlations between FF Conductivity and Chloride $(\mathrm{r}=0.92)$, as well as FF pH and Conductivity and between $\mathrm{FF}$ and $\mathrm{RR} \mathrm{pH}$, as the $\mathrm{H}^{+}$ions dissolved in the water also lead to an increase of Conductivity.
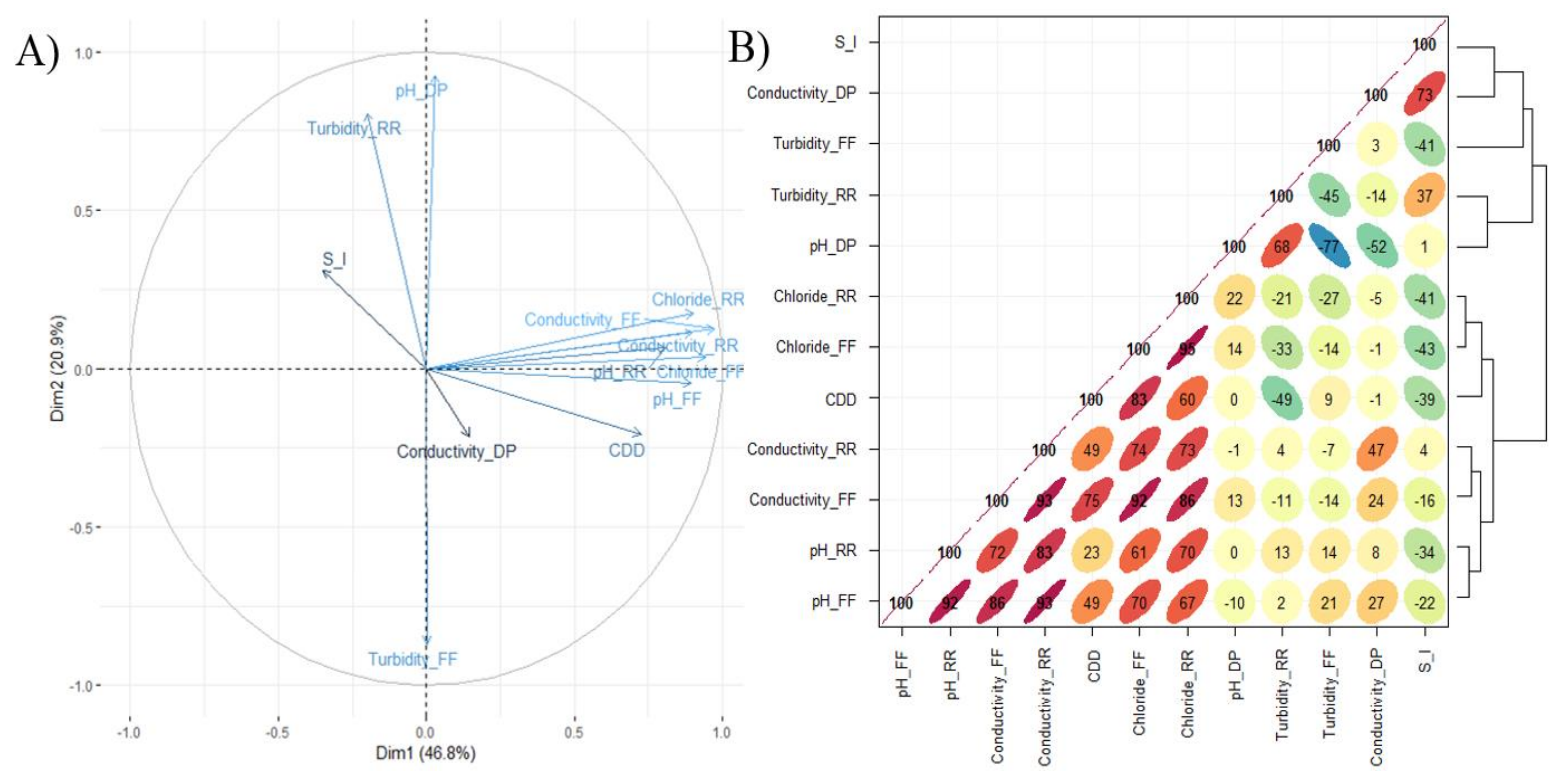

Figure 5. (A) Principal component analysis (PCA) and (B) Pearson correlation matrix, together with a hierarchical cluster analysis (HCA) of physico-chemical and meteorological parameters in the dry period of direct precipitation (DP), first flush (FF) and reservoir (RR). CDD: Consecutive dry days; S_I: Sub - diurnal rainfall intensity.

\subsection{Metal}

In the wet period, metals (with the exception of $\mathrm{Na}$ ) are above the permissible limit set by Ordinance $\mathrm{n}^{\circ} 05 / 2017$ in at least one sample. The FF can obtain $42.85 \%$ of non-compliant results, which assists in reducing the concentration of metals at the RR point; however, it is not effective enough to reduce this concentration to the recommended limit. In the dry period, metals have a lower concentration than in the wet period, and in the case of FF, $22.85 \%$ of the samples are above what is permissible (Table 2 and Figure 6 and 7).

The samples collected in the dry season had the highest Ca concentrations and were lower in the wet season. The highest mean Ca value that was obtained for the FF samples was 33.16 $\pm 28.4 \mathrm{mg} \mathrm{L}^{-1}$ in the dry season and the lowest mean value which was for the RR samples was $1.12 \pm 0.21 \mathrm{mg} \mathrm{L}^{-1}$ in the wet season. It should be noted that the dominant components were crustal, which increases the alkalinity of the rainwater because it includes components such as $\mathrm{Mg}$ and $\mathrm{Ca}$ (Kulshrestha et al., 2003). There are many possible sources of $\mathrm{Ca}$, such as marine aerosols, soil particle resuspension and road dust (Ali et al., 2004), and these can neutralize the acidity of rainwater (Han et al., 2011). The legislation does not stipulate if there are any permissible limits for $\mathrm{Ca}$. 
Table 2. Descriptive statistics for the metal concentrations and meteorological parameters in the wet period and the dry period.

\begin{tabular}{|c|c|c|c|c|c|c|c|c|c|c|c|c|c|c|c|c|c|c|c|c|c|c|c|c|c|c|c|c|c|c|c|c|}
\hline Parameter & & $\mathrm{Ca}$ & & & $\mathrm{Cd}$ & & & $\mathrm{Cu}$ & & & $\mathrm{Fe}$ & & & K & & & $\mathrm{Mn}$ & & & $\mathrm{Na}$ & & & $\mathrm{Ni}$ & & & $\mathrm{Pb}$ & & & $\mathrm{Zn}$ & & $\mathrm{CDD}$ & $S_{-} I$ \\
\hline \multicolumn{33}{|c|}{ Wet } \\
\hline $\begin{array}{l}\text { Ordinance } \\
5 / 2017\end{array}$ & & & & & 0.005 & & & 2 & & & 0.3 & & & & & & 0.1 & & & 200 & & & 0.07 & & & 0.01 & & & 5 & & & \\
\hline Point & DP & FF & $\mathrm{RR}$ & DP & FF & $\mathrm{RR}$ & DP & FF & $\mathrm{RR}$ & DP & FF & $\mathrm{RR}$ & DP & FF & $\mathrm{RR}$ & DP & FF & $\mathrm{RR}$ & DP & FF & $\mathrm{RR}$ & DP & $\mathrm{FF}$ & $\mathrm{RR}$ & DP & FF & $\mathrm{RR}$ & DP & FF & $\mathrm{RR}$ & & \\
\hline Average & 3.56 & 9.78 & 1.12 & 0.02 & 0.02 & 0.02 & 0.95 & 13.83 & 3.54 & 1.04 & 4.74 & 1.48 & 10.42 & 14.23 & 9.82 & 0.04 & 0.60 & 0.04 & 19.13 & 19.89 & 20.83 & 0.21 & 0.33 & 0.13 & & 0.04 & & 0.91 & 3.71 & 3.02 & 4.00 & 9.37 \\
\hline Median & 2.36 & 6.12 & 1.05 & 0.02 & 0.02 & 0.02 & 0.76 & 13.46 & 1.97 & 0.92 & 3.81 & 0.86 & 9.48 & 14.61 & 10.37 & 0.04 & 0.26 & 0.04 & 18.82 & 20.90 & 19.48 & 0.21 & 0.24 & 0.14 & & 0.04 & & 1.00 & 2.85 & 2.70 & 3.00 & 3.07 \\
\hline SD & 3.28 & 9.69 & 0.21 & 0.00 & 0.02 & 0.00 & 0.39 & 11.71 & 5.12 & 0.53 & 4.33 & 1.37 & 2.35 & 1.52 & 4.44 & 0.02 & 0.78 & 0.03 & 5.28 & 7.01 & 2.78 & 0.05 & 0.34 & 0.04 & & 0.04 & & 0.36 & 2.30 & 0.88 & 3.83 & 11.88 \\
\hline Minimum & 1.00 & 3.44 & 0.89 & 0.02 & 0.01 & 0.01 & 0.59 & 0.04 & 0.36 & 0.38 & 0.39 & 0.26 & 8.29 & 10.90 & 1.06 & 0.01 & 0.16 & 0.01 & 8.77 & 5.02 & 17.80 & 0.17 & 0.08 & 0.09 & & 0.01 & & 0.29 & 2.75 & 2.61 & 1.00 & 1.24 \\
\hline Maximum & 10.56 & 31.11 & 1.53 & 0.02 & 0.06 & 0.02 & 1.57 & 31.34 & 13.78 & 1.91 & 10.59 & 4.23 & 14.61 & 15.46 & 15.67 & 0.06 & 1.98 & 0.09 & 25.74 & 27.16 & 25.22 & 0.25 & 0.92 & 0.17 & & 0.06 & & 1.32 & 8.93 & 5.02 & 12.00 & 30.80 \\
\hline
\end{tabular}

\begin{tabular}{|c|c|c|c|c|c|c|c|c|c|c|c|c|c|c|c|c|c|c|c|c|c|c|c|c|c|c|c|c|c|c|c|c|}
\hline & & & & & & & & & & & & & & & D & & & & & & & & & & & & & & & & & \\
\hline Point & DP & FF & $\mathrm{RR}$ & DP & FF & $\mathrm{RR}$ & DP & $\mathrm{FF}$ & $\mathrm{RR}$ & DP & FF & $\mathrm{RR}$ & DP & FF & $\mathrm{RR}$ & DP & FF & $\mathrm{RR}$ & DP & FF & $\mathrm{RR}$ & DP & FF & $\mathrm{RR}$ & DP & FF & $\mathrm{RR}$ & DP & FF & $\mathrm{RR}$ & & \\
\hline Average & 19.25 & 33.16 & 10.31 & 0.02 & 0.02 & 0.02 & & & 1.85 & 0.16 & 1.64 & 0.08 & 4.17 & 6.98 & 3.88 & 0.28 & 0.39 & 0.22 & 5.99 & 6.49 & 4.58 & 0.25 & 0.30 & 0.60 & 0.01 & 0.01 & 0.01 & 1.41 & 4.05 & 3.57 & 1.67 & 4.19 \\
\hline Median & 18.11 & 19.88 & 10.94 & 0.02 & 0.01 & 0.02 & & & 0.36 & 0.13 & 0.90 & 0.03 & 2.81 & 6.04 & 2.71 & 0.30 & 0.37 & 0.22 & 1.99 & 2.20 & 1.79 & 0.25 & 0.30 & 0.60 & 0.01 & 0.01 & 0.01 & 1.44 & 2.57 & 2.54 & 0.00 & 0.95 \\
\hline SD & 10.20 & 28.40 & 5.86 & 0.01 & 0.01 & 0.01 & & & 3.11 & 0.12 & 1.62 & 0.12 & 3.96 & 4.67 & 3.05 & 0.09 & 0.10 & 0.02 & 10.10 & 10.46 & 7.39 & & & & 0.00 & 0.00 & & 0.40 & 3.63 & 2.53 & 2.58 & 6.74 \\
\hline Minimum & 7.60 & 16.00 & 1.99 & 0.01 & 0.01 & 0.01 & & & 0.19 & 0.04 & 0.44 & 0.01 & 1.27 & 2.79 & 2.04 & 0.19 & 0.30 & 0.19 & 1.29 & 1.87 & 0.97 & 0.25 & 0.30 & 0.60 & 0.01 & 0.01 & 0.01 & 0.93 & 2.51 & 2.51 & 0.00 & 0.57 \\
\hline Maximum & 33.02 & 89.45 & 16.21 & 0.02 & 0.03 & 0.03 & & & 6.51 & 0.34 & 4.47 & 0.33 & 11.96 & 15.37 & 9.94 & 0.41 & 0.55 & 0.25 & 26.58 & 27.83 & 19.63 & 0.25 & 0.30 & 0.60 & 0.01 & 0.01 & 0.01 & 1.92 & 11.47 & 8.73 & 5.00 & 17.6 \\
\hline
\end{tabular}



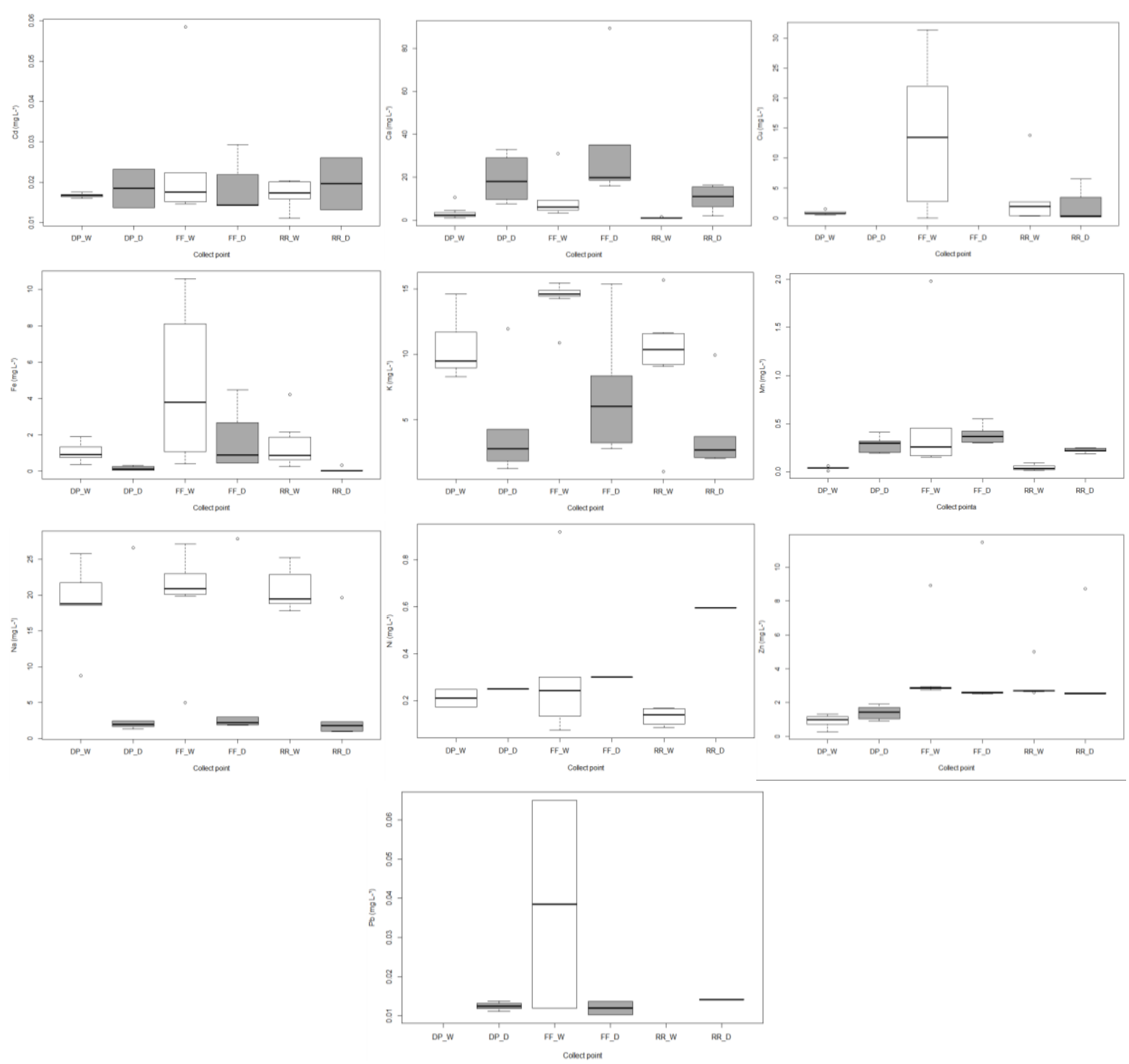

Figure 6. Boxplot for metal concentrations collected in the wet period (W) - shown in grey - and dry (D) - shown in white, at the points of direct precipitation (DP), first flush (FF) and reservoir (RR).

The average for the $\mathrm{Cd}$ at DP, FF and RR points, in both periods, was above the maximum permitted value of $0.005 \mathrm{mg} \mathrm{L}^{-1}$. In the dry season, about $61 \%$ of the results for the concentration were below the limit of quantification (LQ). Studies have suggested that the corrosion of galvanized metallic structures exposed to the urban atmosphere may be responsible for high concentrations of $\mathrm{Cd}$, as well as the proximity of highways (Van Metre and Mahler, 2003), as well as the presence of this metal in the dust that is carried for distances from buildings being repaired or renovated (Miguel et al., 1997). Results above $0.005 \mathrm{mg} \mathrm{L}^{-1}$ have also been found in other rainwater studies (Alcolea et al., 2015), while at the same time there are records of Cd below the limit of quantification (Despins et al., 2009).

The characterization of rainwater in schools in Ghana showed concentrations of $\mathrm{Cd}$ above the limit set by the WHO drinking-water quality guidelines $\left(0.003 \mathrm{mg} \mathrm{L}^{-1}\right)$. This can be attributed to sources such as batteries, automobiles and oil-burning furnaces (Cobbina et al., 2015). Analyses of rainwater in Nigeria found that there were anthropogenic impacts on the environment and that these are linked to a high-level of gas flaring and oil refining activities and obtained $\mathrm{Cd}$ above the recommended $0.003 \mathrm{mg} \mathrm{L}^{-1}$ limit. These are among other factors that can affect these concentrations, such as wind direction and wind speed, $\mathrm{pH}$, the rainfall index and particulate matter concentration (Akintola et al., 2018). 

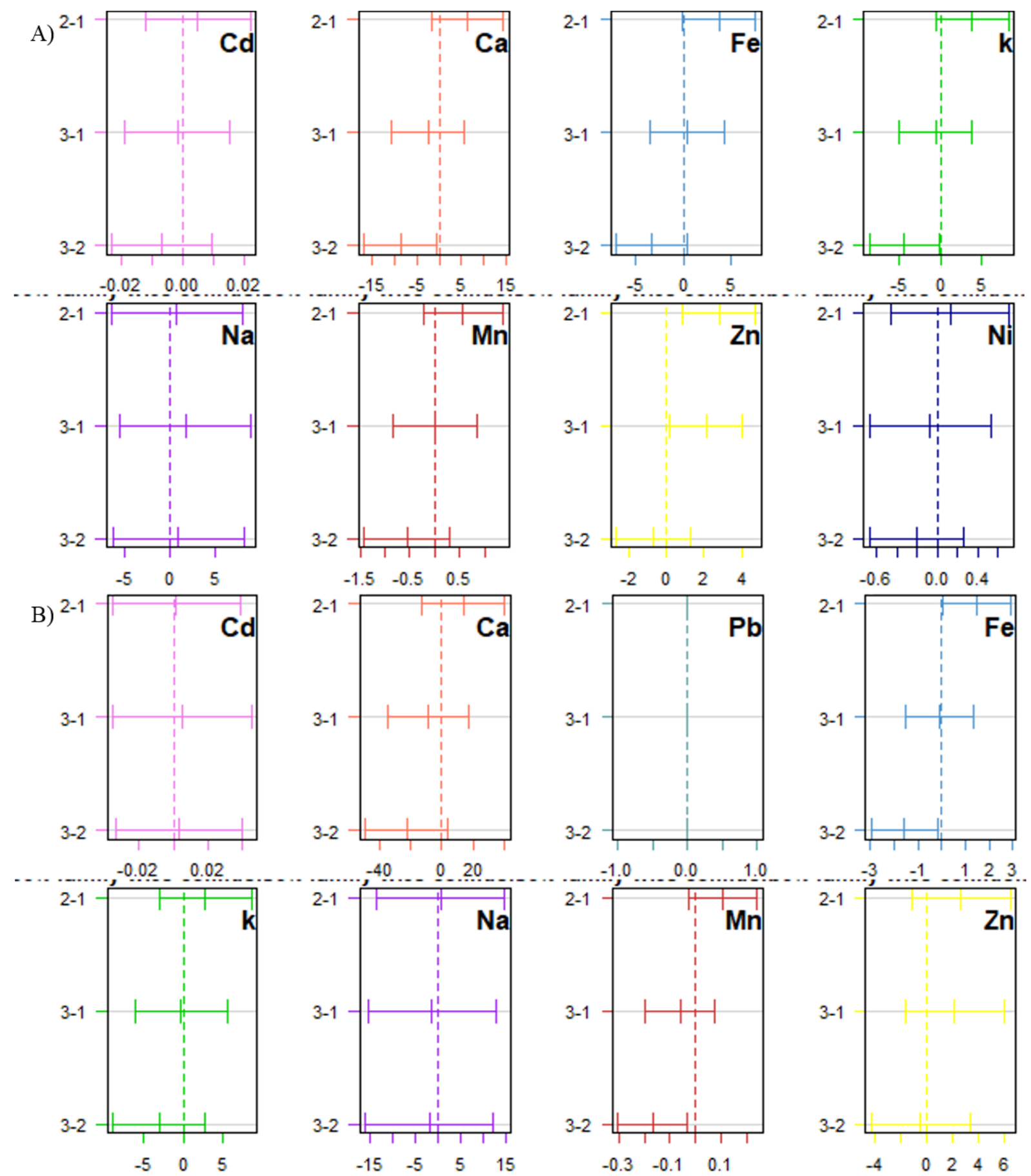

Figure 7. Tukey test metals in the wet period (A) and dry (B), at the points of direct precipitation (1), first flush (2) and reservoir (3).

$\mathrm{Cu}$ has a seasonal behavior with higher concentrations in the wet season. In the rainy season, DP had an average value of $0.95 \pm 0.39 \mathrm{mg} \mathrm{L}^{-1}$, unlike the FF samples, where there were high concentrations with a mean value of $13.83 \pm 11.71 \mathrm{mg} \mathrm{L}^{-1}$. The disposal of rainwater (FF) significantly reduced the copper concentration in the water stored in the RR, which had an average of $3.54 \pm 5.12 \mathrm{mg} \mathrm{L}^{-1}$; despite this, in most of the analyzed samples the reduction was not enough to comply with the legislation. Since rainwater is slightly acidic and contains few dissolved minerals, it can dissolve metals and other impurities that can be found in the storage tank, and this causes discoloration, as well as a bad taste and odor in the harvested rainwater (Sánchez et al., 2015). The seasonal variation of $\mathrm{Cu}$ can be influenced by local contamination or by sources of air masses that have a pattern of behavior that varies between the seasons (Kim 
et al., 2000).

In both periods, the FF showed a high concentration of Fe, which might be influenced by the dry deposition on the roof where there are particles containing $\mathrm{Fe}$ that are removed by the first millimeters of rain. Iron is generally classified as an element which naturally originates from the earth's crust (Nadzir et al., 2017). However, in the characterization of rain in a study carried out in Spain, it was concluded that iron was emitted from anthropogenic sources, on the basis of an analysis of retrograde trajectories and the fouling factor that reveals the non-crustal origin of this metal (Moreda-Piñeiro et al., 2014). In fine particles, the presence of iron can be attributed to the corrosion of the internal parts of vehicles and exhaust pipes (Loyola et al., 2012). This is because the study site has an urban profile, which can cause emissions of ironcontaining compounds, either anthropogenic or of natural origin, due to its proximity to the Tijuca massif.

Potassium is an element that can be found in the environment and in all-natural waters (WHO, 2008), and the presence of this element was observed during the dry and wet season. In the rainy season, the concentration increased in all the samples. In the rainy season, the $\mathrm{K}$ concentration increased at all points. In regions close to the ocean, rainwater has a marine influence on elements such as potassium (Tomaz, 2010; Vázquez et al., 2003). Other studies have shown that $\mathrm{K}$ originates from biogenic sources such as aerosols containing leaf fragments, pollen (Forti et al., 2000; Pauliquevis et al., 2012) or air masses containing compounds from biomass burning (Vieira-Filho et al., 2013).

The mean $\mathrm{Mn}$ values in the wet season were $0.04 \pm 0.02 \mathrm{mg} \mathrm{L}^{-1}$ for DP, $0.60 \pm$ $0.78 \mathrm{mg} \mathrm{L}^{-1}$ for $\mathrm{FF}$ and $0.04 \pm 0.03 \mathrm{mg} \mathrm{L}^{-1}$ for RR. A similar concentration of $\mathrm{Mn}$ in wet deposition was found in rainwater samples in Santa Maria, Rio Grande do Sul and Greece (Hagemann and Gastaldini, 2016; Melidis et al., 2007). In the dry season, only the samples of May 2018 were below the limit of quantification (LQ). The other samples had high concentrations for DP, FF and RR with average values of $0.28 \pm 0.09 \mathrm{mg} \mathrm{L}^{-1}, 0.39 \pm 0.10 \mathrm{mg}$ $\mathrm{L}^{-1}$ and $0.22 \pm 0.02 \mathrm{mg} \mathrm{L}^{-1}$, respectively.

The Mn concentrations in the rainfall are higher in the spring and winter, but lower in the summer and may be caused by changes in the source of pollutants that can be attributed to the wind direction, which has a seasonal effect (Cheng et al., 2011). An evaluation of total suspended particulates in urban areas in South-East Brazil concluded that Mn concentrations were significantly higher in the dry season and may have resulted from changes in the rainfall pattern (Machado et al., 2018).

A study carried out in Rio de Janeiro for $\mathrm{PM}_{2.5}$ samples showed that Mn usually originates from traffic, soil-related sources or raw material in the steel industry (Mateus and Gioda, 2017). The initial disposal system proved to be effective in reducing the concentration of this compound in the reservoir to a level below that recommended by the guidelines of Ordinance $\mathrm{n}^{\circ}$ 05/2017 (0.1 mg L $\left.{ }^{-1}\right)$. During the whole sampling campaign, $\mathrm{Na}$ had the highest concentration in the rainy season, ranging from 5.02 to $27.16 \mathrm{mg} \mathrm{L}^{-1}$ for FF samples and a mean average of $19.13 \pm 5.28 \mathrm{mg} \mathrm{L}^{-1}$ for DP and $20.83 \pm 2.78 \mathrm{mg} \mathrm{L}^{-1}$ for RR. There was a lower variation for $\mathrm{Na}$ results in the dry season, with the highest observed mean average of $6.49 \pm$ $10.56 \mathrm{mg} \mathrm{L}^{-1}$ for $\mathrm{FF}$, while the other samples had a mean of $5.99 \pm 10.10 \mathrm{mg} \mathrm{L}^{-1}$ for DP and $4.58 \pm 7.39 \mathrm{mg} \mathrm{L}^{-1}$ for RR. The system for the capture and storage of rainwater located near the coast of Rio de Janeiro can lead to higher Na levels, since it is present in the composition of marine aerosols (Al-Momani, 2003). All the points showed results within the $200 \mathrm{mg} \mathrm{L}^{-1}$ limit. Water-soluble Na content results in marine spray (Singh et al., 2007; Soluri et al., 2007; Szép et al., 2019), and leads to the highest concentrations in the rainy season, when it is transported over long distances and via dry or wet deposition (Silva et al., 2017). Studies on PM in Rio de Janeiro have shown that there is a higher Na concentration during March and April, which was also observed in this study (Quiterio et al., 2004). 
A reduction in Ni concentration was observed at the reservoir point (unlike the first-flush), but it was not enough to comply with the legislation. The highest mean average for Ni samples found in the wet season was $0.33 \pm 0.34 \mathrm{mg} \mathrm{L}^{-1}$ for $\mathrm{FF}$, and the lowest in the RR with $0.13 \pm$ $0.04 \mathrm{mg} \mathrm{L}^{-1}$. Ni can appear as the result of the leaching of tubes, connections, taps and steel, but its presence decreases over a period of time (WHO, 2008). In the dry season, only concentrations of $0.25 \mathrm{mg} \mathrm{L}^{-1}$ in DP, $0.30 \mathrm{mg} \mathrm{L}^{-1}$ in FF and $0.60 \mathrm{mg} \mathrm{L}^{-1}$ in RR were determined in the first collection. Ni has been correlated with anthropogenic activities in several studies (Kim et al., 2000), and also with traffic emissions (Nadzir et al., 2017) and fuel combustion (Gunawardena et al., 2013).

$\mathrm{DP}$ and FF Pb samples in the wet season were below the limit of quantification (LQ). In the $\mathrm{FF}, \mathrm{Pb}$ could only be detected in 2 samples with results of $0.01 \mathrm{mg} \mathrm{L}^{-1}$ and $0.06 \mathrm{mg} \mathrm{L}^{-1}$. Rainwater systems in Canada also showed levels of $\mathrm{Pb}$ lower than $0.01 \mathrm{mg} \mathrm{L}^{-1}$ in the RR (Despins et al., 2009). In the dry season, samples were also observed below LQ $(\mathrm{N}=12)$. The cause of $\mathrm{Pb}$ emissions is generally attributed to anthropogenic sources (Azimi et al., 2003; Moreda-Piñero et al., 2014), such as factors leading to the wear and tear of vehicles (Egodawatta et al., 2013). In addition, $\mathrm{Pb}$ is also linked to the effects of roadside deposition caused by the accumulation of soil residues, fuel additives (Thorpe and Harrison, 2008) and by emission of exhaust fumes into the atmosphere (Gunawardena et al., 2012; 2015; Zhang et al., 2015).

The $\mathrm{Zn}$ in the FF season showed a sample with high concentration of $11.47 \mathrm{mg} \mathrm{L}^{-1}$ and $\mathrm{RR}$ followed the same pattern with a result of $8.73 \mathrm{mg} \mathrm{L}^{-1}$. Zn was found to be the most abundant ion among the metals detected in rainwater (Vlastos et al., 2019); concentrations below $5 \mathrm{mg}$ $\mathrm{L}^{-1}$ were reported in urban areas and in areas of heavy traffic (Angrill et al., 2017; Gispert et al., 2018). Higher levels of $\mathrm{Zn}$ were detected in rainwater collected from galvanized zinc roofs (Belghazi et al., 2002; Förster, 1996; Simmons et al., 2001) Although the roof of the rainwater catchment system is made of aluminum and zinc, these levels were not found in this study. The $\mathrm{Zn}$ can perhaps be attributed to the traffic of nearby avenues. This metal is generally found on the roads as an organometallic compound used in diesel engine lubricants and in tire wear particles (Ball et al., 1998; Davis et al., 2001; Helmreich et al., 2010; Mangani et al., 2005). Other studies advocate the use of porous pavements to reduce the number of metal pollutants originating from roads ( $\mathrm{Yu}$ and $\mathrm{Zhao}, 2012$ ).

Any metals that had a low variation or led to results below the LQ were not selected for the multivariate statistical analysis. In the PCA for DP during the wet season, it was found that Fe and the S_I have a negative correlation with the other parameters. The formation of 3 clusters was noted in the dendrogram: the first consisted of $\mathrm{CDD}, \mathrm{Cu}, \mathrm{Zn}$ and $\mathrm{Na}$ correlated with the second cluster formed by $\mathrm{Ca}, \mathrm{K}$ and $\mathrm{Mn}$ and the third cluster with IN_SUB and Fe.

Pearson's linear correlation matrix used for the wet season for DP, shows that $\mathrm{K}$ and $\mathrm{Ca}$ have the highest correlation ( $\mathrm{r}=0.98)$. Na and $\mathrm{Zn}(\mathrm{r}=0.94), \mathrm{Mn}$ and $\mathrm{Ca}(\mathrm{r}=0.88)$ and $\mathrm{Mn}$ and $\mathrm{K}(\mathrm{r}=0.79)$ also have high correlations and may have the same natural and / or anthropogenic origin. $\mathrm{Cu}$ has negative correlations with most metals, which suggests it is of a different origin from the others; the same pattern of behavior was evident for Fe. Zn has moderate correlation with $\mathrm{Cu}$, which suggests that $\mathrm{Zn}$ might be of a natural and anthropogenic origin. In the case of the dry season, Ca and S_I in the PCA showed a low correlation with the other parameters. In the dendrogram, there are 3 clusters and the most significant correlations in the dry season were found to be between $\mathrm{Fe}, \mathrm{K}, \mathrm{Na}, \mathrm{Zn}$ and $\mathrm{Mn}$, which probably originate from natural sources. $\mathrm{Ca}$ had low correlations with most of the parameters which suggests a different source of emission (Figure 8). 


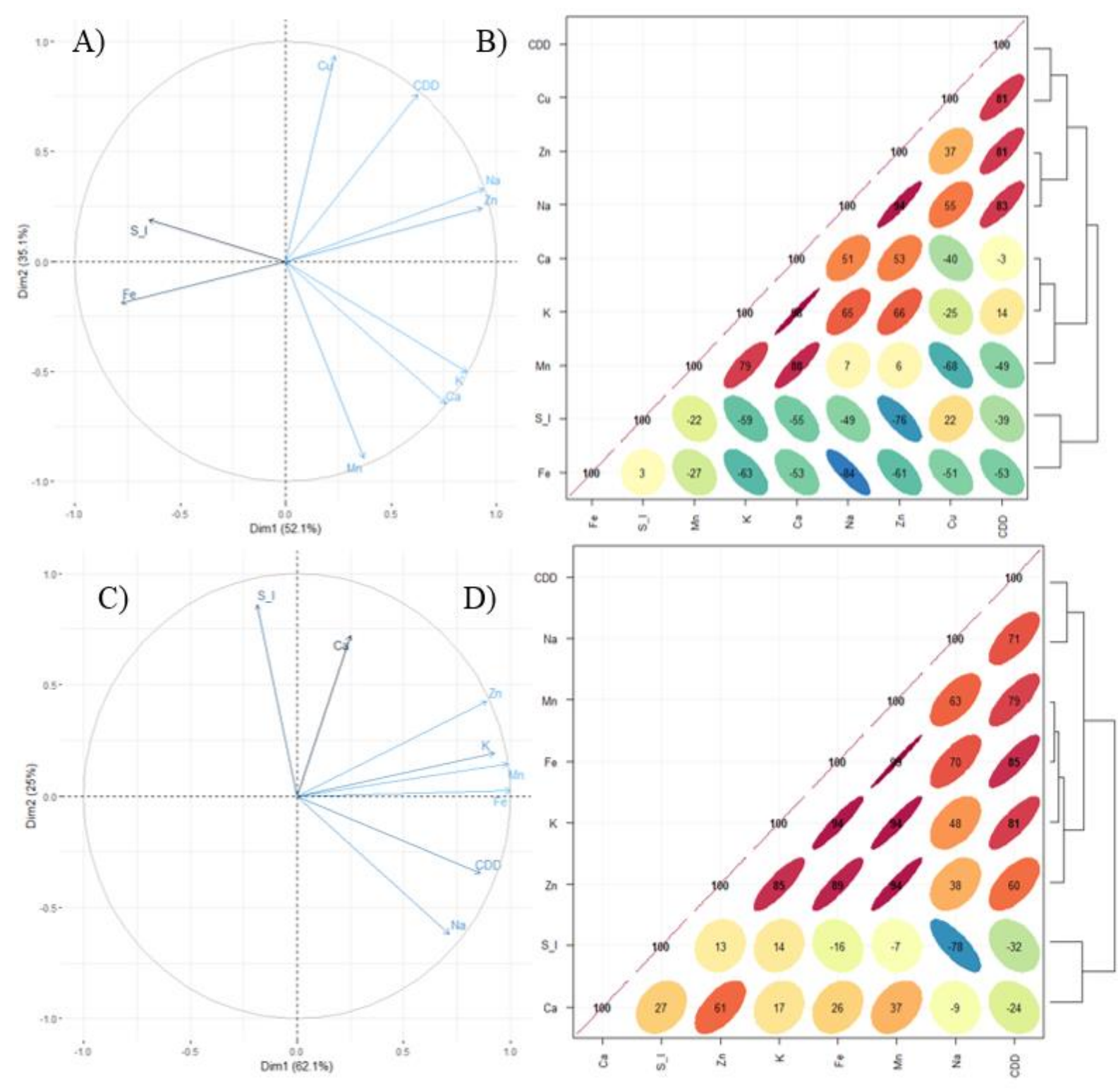

Figure 8. Principal component analysis (PCA) and Pearson correlation matrix, together with the hierarchical cluster analysis (HCA) of physico-chemical and meteorological parameters in direct precipitation (DP): (A, B) in the wet period; $(\mathrm{C}, \mathrm{D})$ in the dry period. CDD: Consecutive dry days; $\mathrm{S} \_\mathrm{I}$ : Sub - diurnal rainfall intensity.

In the FF wet season, the PCA analysis showed a high correlation and a link between $\mathrm{Zn}$ and $\mathrm{Na}$ as contributory factors. The $\mathrm{S} \_\mathrm{I}$ is inversely correlated to the other parameters, as in DP, whereas the S_I is negatively correlated with the metals. Fe has a high correlation with other metals, except for Na and S_I, which shows a low correlation. Despite being correlated with $\mathrm{Mn}, \mathrm{Fe}$ is also correlated with the $\mathrm{Cu}$ and may have natural soil and anthropogenic sources like the vehicular emissions (Loyola et al., 2012). $\mathrm{Cu}$ and $\mathrm{Zn}$ can be attributed to traffic emissions (Gunawardena et al., 2013). In the case of the dry season, the components (Dim 1 and Dim 2) together represent $88.7 \%$ of the data. Fe is the only element in the $3^{\text {rd }}$ quadrant that shows a negative correlation with the other PCA components. According to the dendrogram, two clusters were formed: the first by $\mathrm{S} \_\mathrm{I}$ and $\mathrm{Fe}$ and the second by CDD, $\mathrm{Zn}, \mathrm{Mn}, \mathrm{Ca}, \mathrm{Na}$ and $\mathrm{K}$. Apart from $\mathrm{Fe}$, the other metals have strong and positive correlations with each other. Fe has negative correlations with other metals and probably does not have the same source. The S_I did not influence the concentrations of FF metal data (Figure 9). 


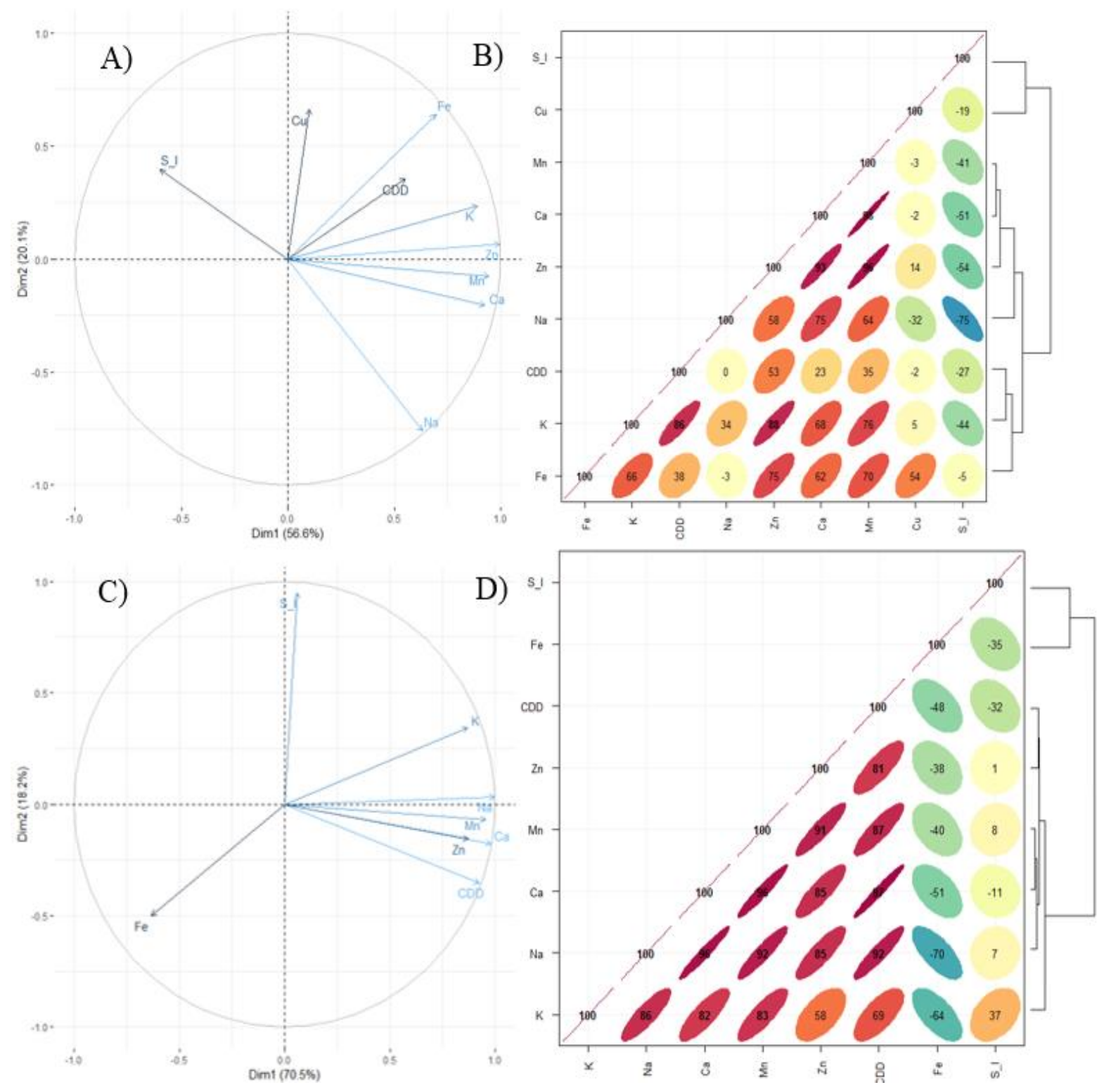

Figure 9. Principal component analysis (PCA) and Pearson correlation matrix, together with the hierarchical cluster analysis (HCA) of physico-chemical and meteorological parameters in first flush (FF): (A, B) in the wet period; $(\mathrm{C}, \mathrm{D})$ in the dry period. CDD: Consecutive dry days; S_I: Sub - diurnal rainfall intensity.

In the reservoir for the wet period, the PCA analysis shows a dispersion of the parameters that represent weaker correlations. In general, $\mathrm{Fe}$ has negative correlations and probably originates from a different source from the other metals. The most significant correlations were: $\mathrm{K}$ and $\mathrm{Cu}, \mathrm{Na}$ and $\mathrm{Cd}$ and $\mathrm{S} \_\mathrm{I}$ and $\mathrm{Ca}$.

There was no variance or contribution made by the CDD vector in the dry period, as there were no consecutive dry days on the dates selected for PCA analysis. It can be seen that the metals are more correlated than in the wet period. The closest correlations occurred between: $\mathrm{Ca}$ and $\mathrm{Cu}, \mathrm{K}$ and $\mathrm{Cu}$ and $\mathrm{Ca}$ and $\mathrm{K}$, probably from the same natural and / or anthropogenic source. The metals that may have had different sources were: Mn and Fe $(r=-0.94)$ and $\mathrm{Mn}$ and $\mathrm{Na}(\mathrm{r}=-0.80)$ (Figure 10). 


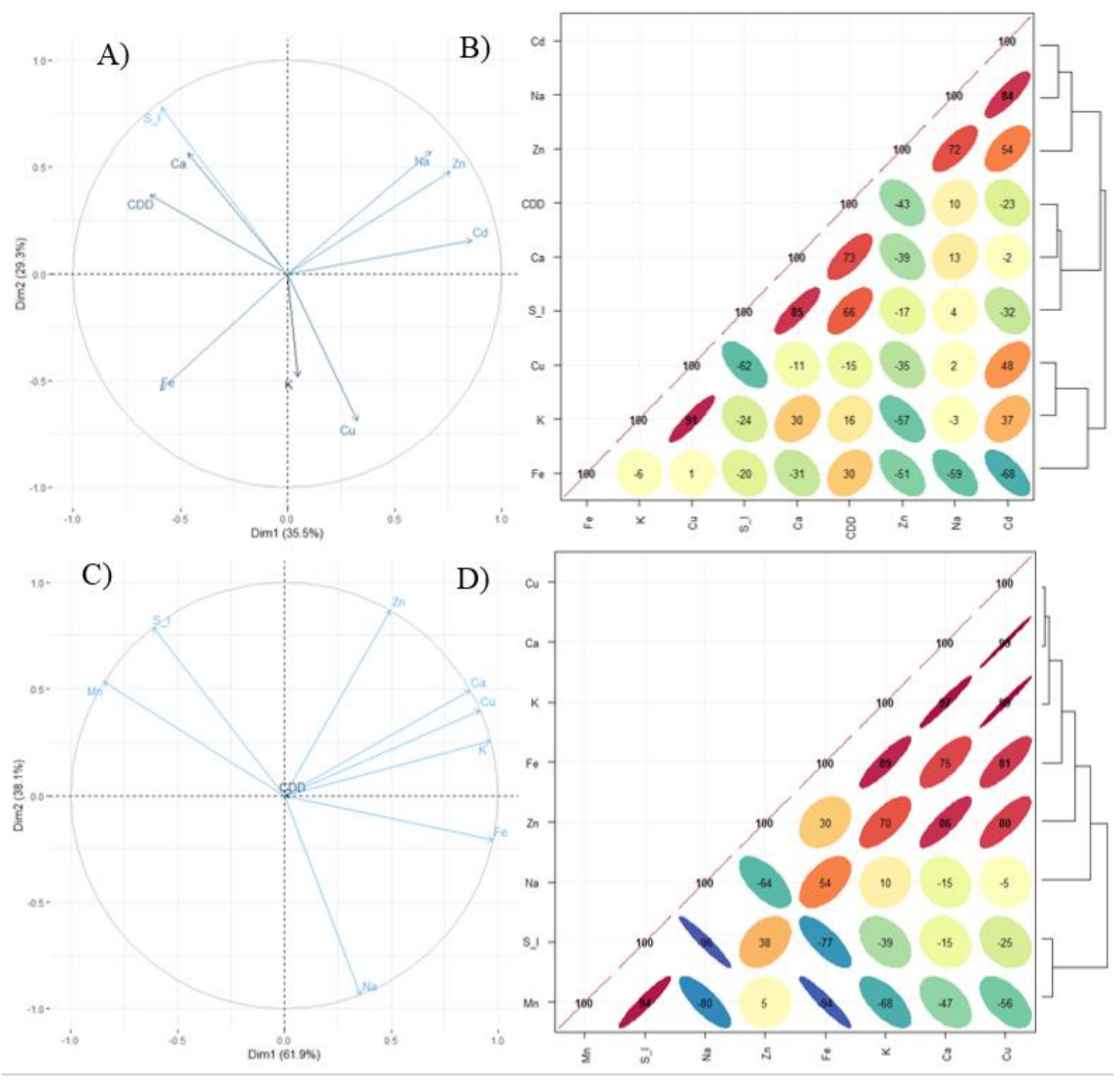

Figure 10. Principal component analysis (PCA) and Pearson correlation matrix, together with the hierarchical cluster analysis (HCA) of physico-chemical and meteorological parameters in reservoir (RR): (A, B) in the wet period; (C, D) in the dry period. CDD: Consecutive dry days; S_I: Sub - diurnal rainfall intensity.

\section{CONCLUSION}

This study carried out a research project into the chemical composition of rainwater at different points of a rainwater capture and storage system. After 1 year of monitoring, the results revealed that $\mathrm{Ca}, \mathrm{K}$ and $\mathrm{Na}$ are the main metals found in rainwater. The $\mathrm{R}$ language was important to evaluate the possible sources and the visualization of groups between the physicalchemical and meteorological parameters. The findings suggest an anthropogenic origin linked to traffic emissions for $\mathrm{Cu}, \mathrm{Zn}$ and $\mathrm{Fe}$. It was found that $\mathrm{Na}, \mathrm{K}, \mathrm{Ca}, \mathrm{Mn}$ and $\mathrm{Fe}$ may have a natural origin. Wet deposition is characterized by a low concentration of metals. However, when it comes into contact with the catchment surface, rainwater has a high concentration of pollutants, demonstrating the impact of urbanization on the quality of rainwater. It is suggested that the volume of discard be increased to decrease pollutants that reach the reservoir. The high concentration of metals in the wet period suggests that rain assists the cleaning of the atmosphere and that most metals are present in the form of aerosols and fine particles suspended 
in the air. It was thus concluded that rainwater is not suitable for drinking purposes; pretreatment is essential to ensure rainwater can be used safely for more mundane purposes. In future studies, it is recommended that the cations and anions of metals in rainwater be investigated to determine the existence of long-term volatile organic compounds, in addition to investigating the potential impact of metal contamination on human health.

\section{ACKNOWLEDGMENTS}

The financial support from the Rio de Janeiro Foundation for Research Assistance (FAPERJ), Brazilian National Council for Scientific and Technological Development (CNPq) and Financier of Studies and Projects (FINEP) by the Project for the Management of Urban Water Pluvial Waters (MAPLU).

\section{REFERENCES}

ABU-ZREIG, M.; ABABNEH, F.; ABDULLAH, F. Assessment of rooftop rainwater harvesting in northern Jordan. Physics and Chemistry of the Earth, Parts $\mathbf{A} / \mathbf{B} / \mathbf{C}$, v. 114, p. 102794, 2019. https://doi.org/10.1016/j.pce.2019.08.002

AKINTOLA, O. A.; SANGODOYIN, A. Y.; AGUNBIADE, F. O. Anthropogenic activities impact on atmospheric environmental quality in a gas-flaring community: application of fuzzy logic modelling concept. Environmental Science and Pollution Research, v. 25, n. 22, p. 21915-21926, 2018. http://dx.doi.org/10.1007/s11356-018-2295-5

AL-MOMANI, I. F. Trace elements in atmospheric precipitation at Northern Jordan measured by ICP-MS : acidity and possible sources. Atmospheric Environment, v. 37, p. 45074515, 2003. http://dx.doi.org/10.1016/S1352-2310(03)00562-4

ALCOLEA, A.; FERNÁNDEZ-LÓPEZ, C.; VÁZQUEZ, M.; CAPARRÓS, A.; IBARRA, I.; GARCÍA, C.; ZARROCA, M.; RODRÍGUEZ, R. An assessment of the influence of sulfidic mine wastes on rainwater quality in a semiarid climate (SE Spain). Atmospheric Environment, v. 107, p. 85-94, 2015. http://dx.doi.org/10.1016/j.atmosenv.2015.02.028

ALERTA RIO. Sistema Alerta Rio da Prefeitura do Rio de Janeiro. 2018. Available at: http://alertario.rio.rj.gov.br/download/dados-pluviometricos/. Access: jun. 2020.

ALI, K.; MOMIN, G. A.; TIWARI, S.; SAFAI, P. D.; CHATE, D. M.; RAO, P. S. P. Fog and precipitation chemistry at Delhi, North India. Atmospheric Environment, v. 38, p. 4215-4222, 2004. http://dx.doi.org/10.1016/j.atmosenv.2004.02.055

ALIM, M. A.; RAHMAN, A.; TAO, Z.; SAMALI, B.; KHAN, M. M.; SHIRIN, Suitability of roof harvested rainwater for potential potable water production: A scoping review. $\begin{array}{llllll}\text { Journal of Cleaner Production, v. 248, p. 119226, } 2020 . & \end{array}$ http://dx.doi.org/10.1016/j.jclepro.2019.119226

ANA (Brasil). Guia Nacional de Coleta e Preservação de Amostras - Água, Sedimento, Comunidades Aquáticas e Efluentes Líquidos. Brasília, 2011.

ANA (Brasil). Conjuntura dos recursos hídricos no Brasil 2019: informe anual. Brasília, 2019.

ANGRILL, S.; PETIT-BOIX, A.; MORALES-PINZÓN, T.; JOSA, A.; RIERADEVALL, J.; GABARRELL, X. Urban rainwater runoff quantity and quality - A potential endogenous resource in cities? Journal of Environmental Management, v. 189, p. 14-21, 2017. http://dx.doi.org/10.1016/j.jenvman.2016.12.027 
ANIL, I.; ALAGHA, O.; KARACA, F. Effects of transport patterns on chemical composition of sequential rain samples: trajectory clustering and principal component analysis approach. Air Quality, Atmosphere and Health, v. 10, n. 10, p. 1193-1206, 2017. http://dx.doi.org/10.1007/s11869-017-0504-x

APHA; AWWA; WEF. Standard Methods for the examination of water and wastewater. 22nd ed. Washington, 2012. 1496 p.

AZIMI, S.; LUDWIG, A.; THÉVENOT, D. R.; COLIN, JL. Trace metal determination in total atmospheric deposition in rural and urban areas. The Science of the total environment, v. 308, n. 1, p. 247-256, 2003. http://dx.doi.org/10.1016/S0048-9697(02)00678-2

BALL, J. E.; JENKSB, R.; AUBOURG, D. An assessment of the availability of pollutant constituents on road surfaces. The Science of the total environment, v. 209, p. 243-254, 1998. http://dx.doi.org/10.1016/S0048-9697(98)80115-0

BELGHAZI, A.; BOHM, S.; SULLIVAN, J. H.; WORSLEY, D. A. Zinc runoff from organically coated galvanised architectural steel. Corrosion Science, v. 44, n. 8, p. 1639 1653, 2002. http://dx.doi.org/10.1016/S0010-938X(01)00176-7

BELÓ, A.; QUINÁIA, S. P.; DE OLIVEIRA, N. K.; WATZLAWICK, L. F. Caracterização de metais em precipitação atmosférica em uma Floresta Ombrófila Mista. Ambiente e Agua - An Interdisciplinary Journal of Applied Science, v. 4, n. 2, p. 200-211, 2009. http://dx.doi.org/10.4136/1980-993X

BRAGA, A. L.; ARBILLA, G.; SILVA, C. M. Planejamento urbano e qualidade do ar. Um estudo de caso: o papel da Floresta da Tijuca na cidade do Rio de Janeiro. Revista Aquila, n. 19 , p. $8-15,2018$.

BRASIL. Ministério da Saúde. Portaria de Consolidação no 5, de 28 de setembro de 2017. Consolidação das normas sobre as ações e os serviços de saúde do Sistema Único de Saúde. Diário Oficial [da] União: seção 1, Brasília, DF, n. 190, supl., 3 de out. de 2017.

BRATCHELL, N. Cluster Analysis. Chemometrics and Intelligent Laboratory Systems, v. 6, p. 105-125, 1989.

BRITO, T. T.; OLIVEIRA-JÚNIOR, J. F.; LYRA, G. B.; GOIS, G.; ZERI, M. Multivariate analysis applied to monthly rainfall over Rio de Janeiro state, Brazil. Meteorology and Atmospheric Physics, v. 129, n. 5, p. 469-478, 2017. http://dx.doi.org/10.1007/s00703016-0481-x

CAMPISANO, A.; BUTLER, D.; WARD, S.; BURNS, M. J.; FRIEDLER, E.; DEBUSK, K.; FISHER-JEFFES, L. N.; GHISI, E.; RAHMAN, A.; FURUMAI, H.; HAN, M. Urban rainwater harvesting systems: Research, implementation and future perspectives. Water Research, v. 115, p. 195-209, 2017. http://dx.doi.org/10.1016/j.watres.2017.02.056

CERQUEIRA, M. R. F.; PINTO, M. F.; DEROSSI, I. N.; ESTEVES, W. T.; RACHID SANTOS, M. D.; COSTA MATOS, M. A.; LOWINSOHN, D.; MATOS, R. C. Chemical characteristics of rainwater at a southeastern site of Brazil. Atmospheric Pollution Research, v. 5, n. 2, p. 253-261, 2014. http://dx.doi.org/10.5094/APR.2014.031

CHARLSON, R. J.; RODHE, H. Factors controlling the acidity of natural rainwater. Nature, v. 295, p. 683-685, 1982. http://dx.doi.org/10.1038/295683a0 
CHENG, M. C.; YOU, C. F.; LIN, F. J.; HUANG, K. F.; CHUNG, C. H. Sources of Cu, Zn, $\mathrm{Cd}$ and $\mathrm{Pb}$ in rainwater at a subtropical islet offshore northern Taiwan. Atmospheric $\begin{array}{lllllll}\text { Environment, } & \text { v. } 45, \quad \text { n. } 11, \quad \text { p. } & 1919-1928,\end{array}$ http://dx.doi.org/10.1016/j.atmosenv.2011.01.034

COBBINA, S. J.; AGOBOH, Y. P.; DUWIEJUAH, A. B.; BAKOBIE, N. Evaluation of Stored Rainwater Quality in Basic Schools in the Tamale Metropolis, Ghana. Water Quality, Exposure and Health, v. 7, n. 4, p. 583-590, 2015. http://dx.doi.org/10.1007/s12403015-0174-6

CONCEIÇÃO, F. T.; BONOTTO, D. M. Weathering rates and anthropogenic influences in a sedimentary basin, São Paulo State, Brazil. Applied Geochemistry, v. 19, p. 575-591, 2004. http://dx.doi.org/10.1016/j.apgeochem.2003.07.002

CONCEIÇÃO, F. T.; SARDINHA, D. S.; NAVARRO, G. R. B.; ANTUNES, M. L. P.; ANGELUCCI, V. A. Composição química das águas pluviais e deposição atmosférica anual na bacia do alto Sorocaba (SP). Química Nova, v. 34, n. 4, p. 610-616, 2011. http://dx.doi.org/10.1590/S0100-40422011000400011

CONNAN, O.; MARO, D.; HÉBERT, D.; ROUPSARD, P.; GOUJON, R.; LETELLIER, B.; LE CAVELIER, S. Wet and dry deposition of particles associated metals $(\mathrm{Cd}, \mathrm{Pb}, \mathrm{Zn}, \mathrm{Ni}$, $\mathrm{Hg}$ ) in a rural wetland site, Marais Vernier, France. Atmospheric Environment, v. 67, p. 394-403, 2013. http://dx.doi.org/10.1016/j.atmosenv.2012.11.029

D’ALESSANDRO, W.; KATSANOU, K.; LAMBRAKIS, N.; BELLOMO, S.; BRUSCA, L.; LIOTTA, M. Chemical and isotopic characterisation of bulk deposition in the Louros basin (Epirus, Greece). Atmospheric Research, v. 132-133, p. 399-410, 2013. http://dx.doi.org/10.1016/j.atmosres.2013.07.007

DAVIS, A. P.; SHOKOUHIAN, M.; NI, S. Loading estimates of lead, copper, cadmium, and zinc in urban runoff from specific sources. Chemosphere, v. 44, p. 997-1009, 2001. http://dx.doi.org/10.1016/S0045-6535(00)00561-0

DESPINS, C.; FARAHBAKHSH, K.; LEIDL, C. Assessment of rainwater quality from rainwater harvesting systems in Ontario, Canada. Journal of Water Supply: Research $\begin{array}{llllllll}\text { and Technology - } & \text { AQUA, v. 58, n. 2, p. 117-134, }\end{array}$ http://dx.doi.org/10.2166/aqua.2009.013

DIEHL DE SOUZA, T.; GHISI, E. Harvesting rainwater from scaffolding platforms and walls to reduce potable water consumption at buildings construction sites. Journal of Cleaner Production, v. 258, p. 120909, 2020. http://dx.doi.org/10.1016/j.jclepro.2020.120909

EGODAWATTA, P.; ZIYATH, A. M.; GOONETILLEKE, A. Characterising metal build-up on urban road surfaces. Environmental Pollution, v. 176, p. 87-91, 2013. http://dx.doi.org/10.1016/j.envpol.2013.01.021

FORNARO, A.; GUTZ, I. G. Wet deposition and related atmospheric chemistry in the São Paulo metropolis, Brazil: Part 2-contribution of formic and acetic acids. Atmospheric Environment, v. 37, n. 1, p. 117-128, 2003. http://dx.doi.org/10.1016/S13522310(02)00885-3

FÖRSTER, J. Patterns of roof runoff contamination and their potential implications on practice and regulation of treatment and local infiltration. Water Science and Technology, v. 33, n. 6, p. 39-48, 1996. http://dx.doi.org/10.1016/0273-1223(96)00329-0 
FORTI, M. C.; MELFI, A. J.; ASTOLFO, R.; FOSTIER, A. H. Rainfall chemistry composition in two ecosystems in the northeastern Brazilian Amazon (Amapá State). Journal of Geophysical Research, v. 105, n. 23, p. 28895-28905, 2000. http://dx.doi.org/10.1029/2000JD900235

GASPERI, J.; SEBASTIAN, C.; RUBAN, V.; DELAMAIN, M.; PERCOT, S.; WIEST, L.; MIRANDE, C.; CAUPOS, E.; DEMARE, D.; KESSOO, M. D. K.; SAAD, M.; CHWARTZ, J. J.; DUBOIS, P.; FRATTA, C.; WOLFF, H.; MOILLERON, R.; CHEBBO, G.; CREN, C.; MILlET, M.; BARRAUD, S.; GROMAIRE, M. C. Micropollutants in urban stormwater: Occurrence, concentrations, and atmospheric contributions for a wide range of contaminants in three French catchments. Environmental Science and Pollution Research, v. 21, n. 8, p. 5267-5281, 2014. http://dx.doi.org/10.1007/s11356-013-2396-0

GEO-RIO. Relatório Anual de Chuva para a cidade do Rio de Janeiro no ano de 2017. Rio de Janeiro: Fundação Instituto de Geotécnica do Município do Rio de Janeiro, 2018. p. 134.

GHAFFARIANHOSEINI, A.; TOOKEY, J.; GHAFFARIANHOSEINI, A.; YUSOFF, S. M.; HASSAN, N. B. State of the art of rainwater harvesting systems towards promoting green built environments: a review. Desalination and Water Treatment, p. 1-10, 2015. http://dx.doi.org/10.1080/19443994.2015.1021097

GHISI, E.; COLASIO, B. M.; GERALDI, M.; TESTON, A. Rainwater harvesting in buildings in Brazil: A literature review. Proceedings, v. 186, n. 2, p. 1-20, 2018. http://dx.doi.org/10.3390/ecws-2-04955

GIKAS, G. D.; TSIHRINTZIS, V. A. Assessment of water quality of first-flush roof runoff and harvested rainwater. Journal of Hydrology, v. 466-467, p. 115-126, 2012. http://dx.doi.org/10.1016/j.jhydrol.2012.08.020

GIODA, A.; OLIVEIRA, R. C. G.; CUNHA, C. L.; CORRÊA, S. M. Understanding ozone formation at two islands of Rio de Janeiro, Brazil. Atmospheric Pollution Research, v. 9, n. 2, p. 278-288, 2017. http://dx.doi.org/10.1016/j.apr.2017.10.003

GISPERT, M. I.; HERNÁNDEZ, M. A. A.; CLIMENT, E. L.; FLORES, M. F. T. Rainwater harvesting as a drinking water option for Mexico City. Sustainability, v. 10, n. 11, p. 3890-3902, 2018. http://dx.doi.org/10.3390/su10113890

GOMES, U.; DOMÈNECH, L.; PENA, J.; HELLER, L.; PALMIER, L. A Captação de Água de Chuva no Brasil: Novos Aportes a Partir de um Olhar Internacional. Revista Brasileira de Recursos Hídricos, v. 19, n. 1, p. 7-16, 2014. http://dx.doi.org/10.21168/rbrh.v19n1.p7-16

GUNAWARDENA, J.; EGODAWATTA, P.; AYOKO, G. A.; GOONETILLEKE, A. Role of traffic in atmospheric accumulation of heavy metals and polycyclic aromatic hydrocarbons. Atmospheric Environment, v. 54, p. 502-510, 2012. http://dx.doi.org/10.1016/j.atmosenv.2012.02.058

GUNAWARDENA, J.; EGODAWATTA, P.; AYOKO, G. A.; GOONETILLEKE, A. Atmospheric deposition as a source of heavy metals in urban stormwater. Atmospheric $\begin{array}{llllll}\text { Environment, } & \text { v. } & 68, & \text { p. } & 235-242, & \end{array}$ http://dx.doi.org/10.1016/j.atmosenv.2012.11.062 
GUNAWARDENA, J.; ZIYATH, A. M.; EGODAWATTA, P.; AYOKO, G. A.; GOONETILLEKE, A. Sources and transport pathways of common heavy metals to urban road surfaces. Ecological Engineering, v. 77, p. 98-102, 2015. http://dx.doi.org/10.1016/j.ecoleng.2015.01.023

HAGEMANN, S. E.; GASTALDINI, M. C. C. Variação da qualidade da água de chuva com a precipitação: aplicação à cidade de Santa Maria - RS. Revista Brasileira de Recursos Hídricos, v. 21, n. 3, p. 525-536, 2016. http://dx.doi.org/10.1590/2318-0331.011615010

HAN, G.; WU, Q.; TANG, Y. Acid rain and alkalization in southwestern China: chemical and strontium isotope evidence in rainwater from Guiyang. Journal of Atmospheric Chemistry, v. 68, n. 2, p. 139-155, 2011. http://dx.doi.org/10.1007/s10874-012-9213-x

HELMREICH, B.; HILLIGES, R.; SCHRIEWER, A.; HORN, H. Runoff pollutants of a highly trafficked urban road - Correlation analysis and seasonal influences. Chemosphere, v. 80, n. 9, p. 991-997, 2010. http://dx.doi.org/10.1016/j.chemosphere.2010.05.037

HOINASKI, L.; FRANCO, D.; HAAS, R.; MARTINS, R. F.; LISBOA, H. M. Investigation of rainwater contamination sources in the southern part of Brazil. Environmental $\begin{array}{lllllll}\text { Technology, } & \text { v. } & 35, & \text { n. } & 7, & \text { p. } & 868-881,\end{array}$ http://dx.doi.org/10.1080/09593330.2013.854412

HOSEINZADEH, E.; WEI, C.; SAFARI, M.; GODINI, H. Evaluation of rainwater quality using factor analysis: case study of Khorramabad in western Iran. Desalination and Water Treatment, v. 57, n. 53, p. 25345-25357, 2016. http://dx.doi.org/10.1080/19443994.2016.1154895

IBGE. Rio de Janeiro. 2019. Available at: http://cidades.ibge.gov.br/brasil/rj/rio-dejaneiro/panorama Access: jun. 2020.

IGBINOSA, I.; AIGHEWI, I. T. Quality assessment and public health status of harvested rainwater in a peri-urban community in Edo State of Nigeria. Environmental $\begin{array}{llllllll}\text { Monitoring and Assessment, v. 189, n. 8, p. 405, } 2017 . & \text { n. }\end{array}$ http://dx.doi.org/10.1007/s10661-017-6122-0

KAMANI, H.; HOSEINI, M.; SAFARI, G. H.; JAAFARI, J.; MAHVI, A. H. Study of trace elements in wet atmospheric precipitation in Tehran, Iran. Environmental Monitoring and Assessment, v. 186, n. 8, p. 5059-5067, 2014. http://dx.doi.org/10.1007/s10661014-3759-9

KIM, G.; SCUDLARK, J. R.; CHURCH, T. M. Atmospheric wet deposition of trace elements to Chesapeake and Delaware Bays. Atmospheric Environment, v. 34, n. 20, p. 34373444, 2000. http://dx.doi.org/10.1016/S1352-2310(99)00371-4

KULSHRESTHA, M. J.; KULSHRESTHA, U. C.; PARASHAR, D.; VAIRAMANI, M. Estimation of $\mathrm{SO} 4$ contribution by dry deposition of $\mathrm{SO} 2$ onto the dust particles in India. Atmospheric Environment, v. 37, n. 22, p. 3057-3063, 2003. http://dx.doi.org/10.1016/S1352-2310(03)00290-5

KUS, B.; KANDASAMY, J.; VIGNESWARAN, S.; SHON, H. K. Water quality characterisation of rainwater in tanks at different times and locations. Water Science and Technology, v. 61, n. 2, p. 429-439, 2010a. http://dx.doi.org/10.2166/wst.2010.824

KUS, B.; KANDASAMY, J.; VIGNESWARAN, S.; SHON, H. K. Analysis of first flush to improve the water quality in rainwater tanks. Water Science and Technology, v. 61, n. 2, p. 421-428, 2010b. http://dx.doi.org/10.2166/wst.2010.823 
LAOUALI, D.; GALY-LACAUX, C.; DIOP, B.; DELON, C.; ORANGE, D.; LACAUX, J. P.; AKPO, A.; LAVENU, F.; GARDRAT, E.; CASTERA, P. Long term monitoring of the chemical composition of precipitation and wet deposition fluxes over three Sahelian savannas. Atmospheric Environment, v. 50, p. 314-327, 2012. http://dx.doi.org/10.1016/j.atmosenv.2011.12.004

LE PAPE, P.; AYRAULT, S.; QUANTIN, C. Trace element behavior and partition versus urbanization gradient in an urban river (Orge River, France). Journal of Hydrology, v. 472-473, p. 99-110, 2012. http://dx.doi.org/10.1016/j.jhydrol.2012.09.042

LÊ, S.; JOSSE, J.; HUSSON, F. FactoMineR: An R Package for Multivariate Analysis. Journal of Statistical Software, v. 25, n. 1, p. 1-18, 2008.

LEE, M.; KIM, M.; KIM, Y.; HAN, M. Consideration of rainwater quality parameters for drinking purposes: A case study in rural Vietnam. Journal of Environmental $\begin{array}{lllll}\text { Management, } & \text { v. } & 200, & \text { p. } & 400-406,\end{array}$ http://dx.doi.org/10.1016/j.jenvman.2017.05.072

LOYOLA, J.; ARBILLA, G.; QUITERIO, S. L.; ESCALEIRA, V.; MINHO, A. S. Trace metals in the urban aerosols of Rio De Janeiro city. Journal of the Brazilian Chemical Society, v. 23, n. 4, p. 628-638, 2012. http://dx.doi.org/10.1590/S0103-50532012000400007

LU, H.; YU, S. Spatio-temporal variational characteristics analysis of heavy metals pollution in water of the typical northern rivers, China. Journal of Hydrology, v. 559, p. 787-793, 2018. http://dx.doi.org/10.1016/j.jhydrol.2018.02.081

LUNA, A. S.; PAREDES, M. L. L.; DE OLIVEIRA, G. C. G.; CORREAA, S. M. Prediction of ozone concentration in tropospheric levels using artificial neural networks and support vector machines at Rio de Janeiro, Brazil. Atmospheric Environment, v. 98, p. 98-104, 2014. http://dx.doi.org/ 10.1016/j.atmosenv.2014.08.060

LYRA, W. S.; SILVA, E. C.; ARAÚJO, M. C. U.; FRAGOSO, W. D. Classificação periódica: um exemplo didático para ensinar análise de componentes principais. Química Nova, v. 33, n. 7, p. 1594-1597, 2010. http://dx.doi.org/10.1590/S0100-40422010000700030

MACHADO, G.; ALVES, R. I. S.; SENHUK, A. P. M. S.; FREGONESI, B. M.; ZAGUI, G. S.; NADAL, M.; SIERRA, J.; DOMINGO, J. L.; SEGURA-MUÑOZ, S. I. Avaliação espacial e sazonal das concentrações de partículas totais em suspensão e elementos metálicos associados no ar de uma cidade do sudeste brasileiro. Química Nova, v. 42, n. 1, p. 28-35, 2018. http://dx.doi.org/10.21577/0100-4042.20170297

MAGYAR, M. I.; MITCHELL, V. G.; LADSON, A. R.; DIAPER, C. Lead and other heavy metals: common contaminants of rainwater tanks in Melbourne. Water Down Under, p. 409-417, 2008.

MANGANI, G.; BERLONI, A.; BELLUCCI, F.; TATÀNO, F.; MAIONE, M. Evaluation of the Pollutant Content in Road Runoff First Flush Waters. Water, Air, and Soil Pollution, v. 160, n. 1-4, p. 213-228, 2005. http://dx.doi.org/10.1007/s11270-005-2887-9

MARTINS, E. H.; NOGAROTTO, D. C.; MORTATTI, J.; POZZA, S. A. Chemical composition of rainwater in an urban area of the southeast of Brazil. Atmospheric $\begin{array}{lllllll}\text { Pollution Research, } & \text { v. } 10, \quad \text { n. } & 2, & \text { p. }\end{array}$ http://dx.doi.org/10.1016/j.apr.2018.10.003 
MARTINS, R. S. L.; ABESSA, D. M. S.; FORNARO, A.; BORRELY, S. I. Rainwater toxicity and contamination study from São Paulo Metropolitan Region, Brazil. Environmental Monitoring and Assessment, v. 186, p. 1183-1194, 2014. http://dx.doi.org/10.1007/s10661-013-3448-0

MATEUS, V. L.; GIODA, A. A candidate framework for PM2.5 source identification in highly industrialized urban-coastal areas. Atmospheric Environment, v. 164, p. 147-164, 2017. http://dx.doi.org/10.1016/j.atmosenv.2017.05.025

MATEUS, V. L.; LIMA, J. V; GIODA, C. R.; MACHADO, R. C.; LOBATO, R.; WASIELESKY, W.; MONSERRAT, J. M.; GIODA, A. Laboratory-Based Bioaccumulation Essay for Elements Associated to Particulate Matter in White Shrimps After In Vivo Exposure. Journal of Toxicological Analysis, v. 1, n. 1:2, p. 1-6, 2018.

MELIDIS, P.; AKRATOS, C. S.; TSIHRINTZIS, V. A.; TRIKILIDOU, E. Characterization of rain and roof drainage water quality in Xanthi, Greece. Environmental Monitoring and Assessment, v. 127, n. 1-3, p. 15-27, 2007. http://dx.doi.org/10.1007/s10661-006-9254-1

MIGUEL, E.; LLAMAS, J. F.; CHACÓN, E.; BERG, T.; LARSSEN, S.; ROYSET, O.; VADSET, M. Origin and patterns of distribution of trace elements in street dust: Unleaded petrol and urban lead. Atmospheric Environment, v. 31, n. 17, p. 2733-2740, 1997. http://dx.doi.org/10.1016/S1352-2310(97)00101-5

MIMURA, A. M. S.; ALMEIDA, J. M.; VAZ, F. A. S.; DE OLIVEIRA, M. A. L.; FERREIRA, C. C. M.; SILVA, J. C. J. Chemical composition monitoring of tropical rainwater during an atypical dry year. Atmospheric Research, v. 169, p. 391-399, 2016. http://dx.doi.org/ 10.1016/j.atmosres.2015.11.001

MOITA NETO, J. M.; MOITA, G. C. Uma introdução à análise exploratória de dados multivariados. Química Nova, v. 21, n. 4, p. 467-469, 1998. http://dx.doi.org/10.1590/S0100-40421998000400016

MOREDA-PIÑEIRO, J.; ALONSO-RODRÍGUEZ, E.; MOSCOSO-PÉREZ, C.; BLANCOHERAS, G.; TURNES-CAROU, I.; LÓPEZ-MAHÍA, P.; MUNIATEGUI-LORENZO, S.; PRADA-RODRÍGUEZ, D. Influence of marine, terrestrial and anthropogenic sources on ionic and metallic composition of rainwater at a suburban site (northwest coast of

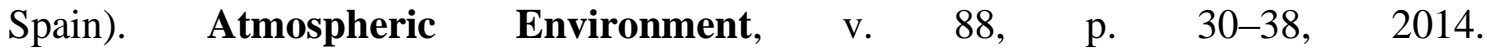
http://dx.doi.org/10.1016/j.atmosenv.2014.01.067

NADZIR, M. S. M.; LIN, C. Y.; KHAN, Md. F.; LATIF, M. T.; DOMINICK, D. HAMID, H. H. A.; MOHAMAD, N.; MAULUD, K. N. A.; WAHAB, M. I. A.; KAMALUDIN, N. F.; LAZIM, M. A. S. M. Characterization of rainwater chemical composition after a Southeast Asia haze event: insight of transboundary pollutant transport during the northeast monsoon. Environmental Science and Pollution Research, v. 24, n. 18, p. 15278-15290, 2017. http://dx.doi.org/10.1007/s11356-017-9131-1

NÉGREL, P.; ROY, S. Chemistry of rainwater in the Massif Central (France): a strontium isotope and major element study. Applied Geochemistry, v. 13, n. 8, p. 941-952, 1998. http://dx.doi.org/10.1016/S0883-2927(98)00029-8

NIU, H.; HE, Y.; XI, X. L.; SHEN, J.; DU, J.; ZHANG, T.; PU, T.; XIN, H.; CHANG, L. Chemical composition of rainwater in the Yulong Snow Mountain region, Southwestern China. Atmospheric Research, v. 144, p. 195-206, 2014. http://dx.doi.org/10.1016/j.atmosres.2014.03.010 
OHNUMA JR, A. A.; PICCOLI, R.; ACCIOLY, W.; MARQUES, M.; SILVA, L. P. A influência da poluição atmosférica na qualidade das águas pluviais. Hydro, v. 9, p. 60$65,2014$.

OLAOYE, R. A.; OLANIYAN, O. S. Quality of Rainwater from Different Roof Material. International Journal of Engineering and Technology, v. 2, n. 8, p. 1413-1421, 2012.

OLIVEIRA, P. L.; FIGUEIREDO, B. R.; CARDOSO, A. A. Rainwater major and trace element contents in southeastern brazil: An assessment of a sugar cane region in dry and wet period. Journal of the Brazilian Chemical Society, v. 23, n. 12, p. 2258-2265, 2012. http://dx.doi.org/10.1590/S0103-50532012001200015

PAULIQUEVIS, T.; LARA, L. L.; ANTUNES, M. L.; ARTAXO, P. Aerosol and precipitation chemistry measurements in a remote site in Central Amazonia: The role of biogenic contribution. Atmospheric Chemistry and Physics, v. 12, n. 11, p. 4987-5015, 2012. http://dx.doi.org/10.5194/acp-12-4987-2012

PAVOLOVÁ, H.; BAKALÁR, T.; KUDELAS, D.; PUŠKÁROVÁ, P. Environmental and economic assessment of rainwater application in households. Journal of Cleaner Production, v. 209, p. 1119-1125, 2019. http://dx.doi.org/10.1016/j.jclepro.2018.10.308

PELICHO, A. F.; MARTINS, L. D.; NOMI, S. N.; SOLCI, M. C. Integrated and sequential bulk and wet-only samplings of atmospheric precipitation in Londrina, South Brazil (1998-2002). Atmospheric Environment, v. 40, n. 35, p. 6827-6835, 2006. http://dx.doi.org/10.1016/j.atmosenv.2006.05.075

QUITERIO, S. L.; SILVA, C. R. S.; ARBILLA, G.; ESCALEIRA, V. Metals in airborne particulate matter in the industrial district of Santa Cruz, Rio de Janeiro, in an annual period. Atmospheric Environment, v. 38, n. 2, p. 321-331, 2004. http://dx.doi.org/10.1016/j.atmosenv.2003.09.017

R CORE TEAM. R: a language and environment for statistical computing. Vienna: R Foundation for Statistical Computing, 2018.

SÁNCHEZ, A. S.; COHIM, E.; KALID, R. A. A review on physicochemical and microbiological contamination of roof-harvested rainwater in urban areas. Sustainability of Water Quality and Ecology, v. 6, p. 119-137, 2015. http://dx.doi.org/10.1016/j.swaqe.2015.04.002

SANUSI, A.; WORTHAM, H.; MILLET, M.; MIRABEL, P. Chemical composition of rainwater in Eastern France. Atmospheric Environment, v. 30, n. 1, p. 59-71, 1996. http://dx.doi.org/10.1016/1352-2310(95)00237-S

SENEVIRATHNA, STMLD; RAMZAN, S.; MORGAN, J. A sustainable and fully automated process to treat stored rainwater to meet drinking water quality guidelines. Process Safety $\begin{array}{llllll}\text { and Environmental Protection, } & \text { v. 130, p. 190-196, }\end{array}$ http://dx.doi.org/10.1016/j.psep.2019.08.005

SICILIANO, W. C.; BASTOS, G. P.; OLIVEIRA, I. T.; SILVA, G. N.; OBRACZKA, M.; OHNUMA JR., A. A. Variabilidade espacial e temporal da precipitação pluvial no município do Rio de Janeiro. Revista Internacional de Ciências, v. 8, n. 2, p. 221-233, 2018. http://dx.doi.org/10.12957/ric.2018.33811 
SILVA, A. M.; CAMPOS, V. P.; DOMINGUES, R. S.; CRUZ, L. P. S.; SANTANA, F. O. Influence of the transport of sea spray on the salinization of the semiarid region waters (Bahia, Brazil). Journal of the Brazilian Chemical Society, v. 28, n. 12, p. 2402-2411, 2017. http://dx.doi.org/10.21577/0103-5053.20170094

SILVA, C. M.; SOUZA, E. C. C. A.; SILVA, L. L.; OlIVEIRA, R. L.; ARBILlA, G.; CORRÊA, S. M. Avaliação da eficiência do método TO-15 para determinação de compostos orgânicos voláteis em condições típicas de ambiente urbano. Química Nova, v. 39, n. 10, p. 1245-1253, 2016a. http://dx.doi.org/10.21577/0100-4042.20160142

SILVA, C. M.; SOUZA, E. C. C. A.; SILVA, L. L.; OLIVEIRA, R. L.; CORRÊA, S. M.; ARBILLA, G. Volatile Organic Compounds in the Atmosphere of the Botanical Garden of the City of Rio de Janeiro: A Preliminary Study. Bulletin of Environmental Contamination and Toxicology, v. 97, n. 5, p. 653-658, $2016 \mathrm{~b}$. http://dx.doi.org/10.1007/s00128-016-1887-3

SIMMONS, G.; HOPE, V.; LEWIS, G.; WHITMORE, J.; GAO, W. Contamination of potable roof-collected rainwater in Auckland, New Zealand. Water Research, Oxford, v. 35, n. 6, p. 1518-1524, 2001. http://dx.doi.org/10.1016/S0043-1354(00)00420-6

SINGH, K. P.; SINGH, V. K.; MALIK, A.; SHARMA, N.; MURTHY, R. C.; KUMAR, R. Hydrochemistry of Wet Atmospheric Precipitation Over an Urban Area in Northern IndoGangetic Plains. Environmental Monitoring and Assessment, v. 131, n. 1-3, p. 237254, 2007. http://dx.doi.org/10.1007/s10661-006-9472-6

SOLURI, D. S.; GODOY, M. L. D. P.; GODOY, J. M.; ROLDÃO, L. A. Multi-site PM2.5 and PM2.5-10 aerosol source apportionment in Rio de Janeiro, Brazil. Journal of the Brazilian Chemical Society, v. 18, n. 4, p. 838-845, 2007. http://dx.doi.org/10.1590/S0103-50532007000400025

SOUZA, P. A.; MELlO, W. Z.; MALDONADO, J.; EVANGELISTA, H. Composição química da chuva e aporte atmosférico na Ilha Grande, RJ. Química Nova, v. 29, n. 3, p. 471-476, 2006. http://dx.doi.org/10.1590/S0100-40422006000300013

SZÉP, R.; BODOR, Z.; MIKLÓSSY, I.; NIȚĂ, I. A.; OPREA, O. A.; KERESZTESI, A. Influence of peat fires on the rainwater chemistry in intra-mountain basins with specific atmospheric circulations (Eastern Carpathians, Romania). Science of The Total $\begin{array}{llllll}\text { Environment, } & \text { v. } & 647, & \text { p. } & 275-289, & \end{array}$ http://dx.doi.org/10.1016/j.scitotenv.2018.07.462

THORPE, A.; HARRISON, R. M. Sources and properties of non-exhaust particulate matter from road traffic: A review. Science of the Total Environment, v. 400, n. 1-3, p. 270282, 2008. http://dx.doi.org/10.1016/j.scitotenv.2008.06.007

TOMAZ, P. Aproveitamento de água de chuva em áreas urbanas para fins não potáveis. Guarulhos, 2010.

UNESCO. The United Nations World Water Development Report 2015: Water for a Sustainable World. Paris, 2015.

VAN METRE, P. C.; MAHLER, B. J. The contribution of particles washed from rooftops to contaminant loading to urban streams. Chemosphere, v. 52, n. 10, p. 1727-1741, 2003. http://dx.doi.org/10.1016/S0045-6535(03)00454-5 
VÁZQUEZ, A.; COSTOYA, M.; PEÑA, R. M.; GARCÍA, S.; HERRERO, C. A rainwater quality monitoring network: a preliminary study of the composition of rainwater in Galicia (NW Spain). Chemosphere, v. 51, n. 5, p. 375-386, 2003. http://dx.doi.org/10.1016/S0045-6535(02)00805-6

VIALlE, C.; SABLAYROLlES, C.; LOVERA, M.; JACOB, S.; HUAU, M. C.; MONTREJAUD-VIGNOLES, M. Monitoring of water quality from roof runoff: Interpretation using multivariate analysis. Water Research, v. 45, n. 12, p. 3765-3775, 2011. http://dx.doi.org/ 10.1016/j.watres.2011.04.029

VIEIRA-FILHO, M. S.; PEDROTTI, J. J.; FORNARO, A. Contribution of long and mid-range transport on the sodium and potassium concentrations in rainwater samples, São Paulo megacity, Brazil. Atmospheric Environment, v. 79, p. 299-307, 2013. http://dx.doi.org/10.1016/j.atmosenv.2013.05.047

VLASTOS, D.; ANTONOPOULOU, M.; LAVRANOU, A.; EFTHIMIOU, I.; DAILIANIS, S.; HELA, D.; LAMBROPOULOU, D.; PASCHALIDOU, A. K.; KASSOMENOS, P. Assessment of the toxic potential of rainwater precipitation: First evidence from a case study in three Greek cities. Science of The Total Environment, v. 648, p. 1323-1332, 2019. http://dx.doi.org/10.1016/j.scitotenv.2018.08.166

WHO. Guidelines for Drinking-Water Quality. Geneva, 2008. 515 p.

WIJESIRI, B.; EGODAWATTA, P.; MCGREE, J.; GOONETILlEKE, A. Assessing uncertainty in pollutant build-up and wash-off processes. Environmental Pollution, v. 212, p. 48-56, 2016. http://dx.doi.org/10.1016/j.envpol.2016.01.051

WU, Q.; HAN, G.; TAO, F.; TANG, Y. Chemical composition of rainwater in a karstic agricultural area, Southwest China: The impact of urbanization. Atmospheric Research, v. 111, p. 71-78, 2012. http://dx.doi.org/10.1016/j.atmosres.2012.03.002

WWAP. The United Nations World Water Development Report 2018: Nature-Based Solutions for Water. Paris, 2018.

YAZIZ, M. I.; GUNTING, H.; SAPARI, N.; GHAZALI, A. W. Variations in rainwater quality from roof catchments. Water Research, v. 23, n. 6, p. 761-765, 1989. http://dx.doi.org/10.1016/0043-1354(89)90211-X

YU, A. H.; ZHAO, C. Evaluation on the highway asphalt pavement runoff with the gray correlation model. Procedia Environmental Sciences, v. 13, p. 1827-1835, 2012. http://dx.doi.org/10.1016/j.proenv.2012.01.176

ZHANG, H.; WANG, Z.; ZHANG, Y.; DING, M.; LI, L. Identification of traffic-related metals and the effects of different environments on their enrichment in roadside soils along the Qinghai-Tibet highway. Science of The Total Environment, v. 521-522, p. 160-172, 2015. http://dx.doi.org/10.1016/j.scitotenv.2015.03.054 